\title{
3 Tuning the properties of nitroxide spin labels for use in electron paramagnetic resonance spectroscopy through chemical modification of the nitroxide framework
}

\section{${ }_{5}$ Janet E. Lovett,* Marius M. Haugland and Edward A. Anderson DOI: 10.1039/b000000x [DO NOT ALTER/DELETE THIS TEXT]}

Spin labels containing nitroxyl radicals possess many properties that render them useful for electron paramagnetic resonance (EPR) spectroscopy. This review describes the relationships between the structure and properties of 10 nitroxide spin labels, methods for their synthesis, advances in methods for their incorporation into biomolecules, and selected examples of applications in biomolecule structural investigations.

\section{Introduction}

Within the field of electron paramagnetic resonance (EPR) spectroscopy, 'spin 15 labelling' describes the attachment of a radical or paramagnetic centre (i.e. a molecule containing at least one unpaired electron spin) onto a material of interest, which enables its investigation using paramagnetic resonance spectroscopy. For such applications, spin labels should ideally fulfil several criteria: The framework of the label must stabilise the radical against redox processes; the radical must possess ${ }_{20}$ desirable properties for the magnetic resonance experiment (such as chemical stability and spin coherence persistence); and, the label must be readily (and sitespecifically) attached without structural distortion of the system under study.

By far the largest family of spin labels are those based on the nitroxyl $(\mathrm{N}-\mathrm{O} \bullet)$ radical, which are called nitroxide spin labels. These are typically five- or six25 membered heterocyclic derivatives of piperidine, pyrrolidine, isoindoline, and other heterocycles containing two heteroatoms; importantly, the nitroxyl radical is flanked by two quaternary carbon atoms. The 'classic' nitroxide is the piperidine-based 2,2,6,6-tetramethylpiperidine 1-oxyl (TEMPO, 1, Figure 1), which has found use in many chemical and materials applications. This radical, in which the unpaired 30 electron is located mainly on the nitrogen and oxygen atoms, is stabilised by the steric screening imparted by its four adjacent methyl groups, which protect the radical from oxidation or other processes. Some other examples of common nitroxide families (2-7) are illustrated.

A 'spin label' can be defined as a derivative of the parent nitroxide in which the 35 core ring system (or its substituents) are modified to enable its incorporation into a
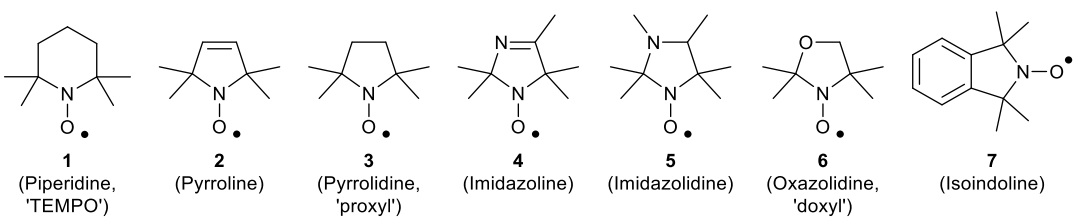

Figure 1: Structures of parent nitroxides.

[journal], [year], [vol], 00-00 | 1 
larger framework, and thus to be used as a probe. The framework of interest may be a polymer, a surface, or a biomolecule such as a protein, nucleic acid, sugar or lipid.

Spin labels are commonly used to measure interspin distances (i.e., the distance between two stable free radicals) using continuous wave $(\mathrm{CW})$ or pulsed techniques, 5 which for nitroxides have an effective range of 0.5 to $>10 \mathrm{~nm}^{1-3}$ They can also be used to probe the local environment of the label, such as its accessibility and dynamic mobility. ${ }^{4}$ Nitroxides are also employed as paramagnetic relaxation enhancers in nuclear magnetic resonance (NMR) spectroscopy, and as polarisation/contrast agents in dynamic nuclear polarization (DNP) or magnetic ${ }_{10}$ resonance imaging (MRI) experiments. ${ }^{5-7}$

Modification of the basic structure of the nitroxide can lead to dramatic changes in the properties of the spin label, and it is for this reason that a myriad of spin labels have been designed. ${ }^{8-18}$ Essential considerations centre on the structure of the nitroxide around the nitroxyl radical itself, and the functionality used to enable spin

15 labelling. This chapter discusses these aspects, along with recent advances in the synthesis and applications of nitroxide spin labels in EPR spectroscopy.

\section{The nitroxide spin label as a probe in EPR spectroscopy}

\subsection{Magnetic properties}

The Zeeman splitting for the nitroxide spin labels is anisotropic and typically $g_{x x}>$ ${ }_{20} g_{y y}>g_{z z}$ with $g_{x x}$ and $g_{y y}$ close in value and greater than the free electron g-value. The $g_{z z}$ axis is roughly coincident with the $\pi$ orbital, approximated as a linear combination of the $2 \mathrm{p}_{\mathrm{z}}$ orbitals of oxygen and nitrogen. Therefore, in planar systems such as pyrrolinoxyl spin labels, the $g_{z z}$ is perpendicular to the plane of the ring. The $\mathrm{x}$-axis is taken as coincident with the NO bond. ${ }^{19}$

25 The unpaired electron is considered to reside in the $\pi$ orbital. The spin density is on the nitrogen and oxygen with almost no delocalisation over the rest of the framework (for adjacent alkyl groups). ${ }^{20,}{ }^{21}$ The Karplus-Fraenkel relationship gives a simple link between atomistic polarisability $(\mathrm{Q})$, spin density $(\rho)$ and isotropic hyperfine coupling constant, $A_{\text {iso }}$, for nitroxide spin labels: $A_{i s o}=\rho_{\mathrm{N}} \mathrm{Q}_{\mathrm{N}}+\rho_{\mathrm{O}} \mathrm{Q}_{\mathrm{O}}$, with ${ }_{30} A_{\text {iso }}$ typically in the region of 40 to $47 \mathrm{MHz} .^{22}$ Due to the relative spin localisation the hyperfine splitting of the Zeeman levels is dominated by the nitrogen of the NO group $\left({ }^{16} \mathrm{O}\right.$ nuclei have zero spin and the predominant isotope of nitrogen is ${ }^{14} \mathrm{~N}$ with a nuclear spin, I, of 1). The hyperfine axes approximately follows the $g$-tensor principal axes with $A_{x x} \approx A_{y y}<A_{z z}$ where $A_{z z}$ is typically about $100 \mathrm{MHz}$. Both $g$ and ${ }_{35} A_{\text {iso }}$ are weakly sensitive to solvent polarity and proticity, with $A_{\text {iso }}$ increasing and $g$ values decreasing in increasingly polar/protic solvents. ${ }^{23,24}$ This property has been used to map membrane protein channels, and to probe changes in solvent behaviour associated with the glass-transition temperature in water/glycerol mixtures. ${ }^{24,25}$

Coupling of proximal nuclei $(I \neq 0)$ to the electron gives rise to the characteristic 40 appearance of an EPR spectrum. Usually, the greatest splitting is caused by coupling to the nitroxyl nitrogen atom, with much smaller splitting from other ring substituents. However, this superhyperfine splitting can afford additional information, such as the extent of protonation of imidazolinyl and imidazolidinyl spin labels. ${ }^{26-30}$ The nature of the substituents flanking the nitroxyl radical can also ${ }_{45}$ significantly affect signal linewidth. ${ }^{31}$ Substituent effects on the ring conformation can be influential: the faster dynamic averaging of the hyperfine interaction of the nitroxyl with the methyl protons in 4-oxo-TEMPO (8) compared to 4-hydroxy-

2 | [journal], [year], [vol], 00-00

This journal is (C) The Royal Society of Chemistry [year] 
TEMPO (9) can be explained by a higher barrier to conformational ring flip in the latter, where the ring framework is fully $\mathrm{sp}^{3}$-hydbridised (aside from the nitroxyl). ${ }^{32}$ Isotopic labelling such as perdeuteration or ${ }^{15} \mathrm{~N}$-substitution, can also lead to line narrowing, and therefore improve the sensitivity of the spin label. ${ }^{33}$ This property 5 has been used to improve the precision of measurement of tumbling rates, and in oximetry. ${ }^{34-36}$

The positioning of certain spin-active nuclei directly adjacent to the nitroxyl can cause more significant splitting. For example, the phosphorus nucleus in PROXYL spin label 10 (Figure 2) has $\mathrm{I}=1 / 2$, with the largest hyperfine coupling at $140 \mathrm{MHz}{ }^{37}$

${ }_{10}$ The resultant two-line spectrum is then split by the nitrogen atom to give a six-line pattern. It was shown that this spin label is a sensitive probe of dynamics, which suggests that it may be possible to simultaneously label a molecule of interest at two sites, with this label and a standard nitroxide, to enable simultaneous but distinguishable measurements.
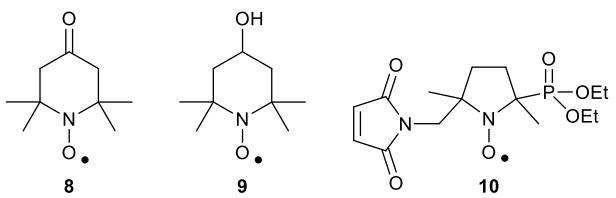

Figure 2: Structures of TEMPO derivatives and a phosphonate-substituted nitroxide.

The anisotropy in the $g$ and $A$ tensors are such that when the spin labels can rotate rapidly, as might be the case in low-viscosity organic solvents at room temperature, the CW EPR spectrum is motionally narrowed and reveals only $g_{\text {iso }}$ and $A_{\text {iso }}$. ${ }_{20}$ However, if the tumbling dynamics of the system are slowed, through increasing viscosity, decreasing temperature, or tethering to a larger, more slowly diffusing molecule, the measured line shape of the nitroxide alters (Figure 3). At X-band microwave frequencies the changes in the lineshape are sensitive to rotational correlation times $\left(\tau_{c}\right)$ in the ns region, with particular sensitivity to changes in ${ }_{25}$ dynamics when $\tau_{c} \sim 1 \mathrm{~ns}$. Altering the microwave frequency will alter the timescales measured and higher frequencies will offer enhanced angular resolution. ${ }^{38,39}$ There are many reports of using this property to map global and local dynamics in spinlabelled proteins. ${ }^{39-47}$

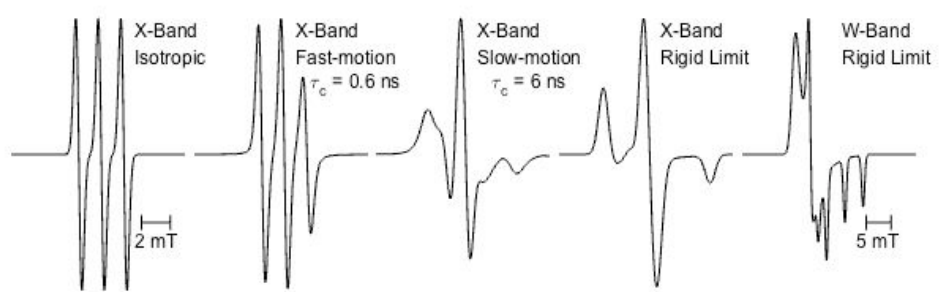

Figure 3: Representation of the link between $\tau_{c}$ and $\mathrm{CW}$ lineshape at X-band microwave frequencies. A comparative W-band CW spectrum shows increased spectral anisotropy. Spectra were simulated with EasySpin using typical parameter values. ${ }^{38,48}$

\subsection{Chemical stability of the radical}

The nitroxyl radical 1 can undergo redox processes to produce the oxammonium ${ }_{35}$ cation 11 (Scheme 1), hydroxylamine 12 or secondary amine $13{ }^{7}$ From the

[journal], [year], [vol], 00-00|3 
viewpoint of maintaining the radical on the spin label (e.g. to enable EPR studies in living cells), protection against reduction to the hydroxylamine is important. The stability of a given nitroxyl radical to reduction is not only determined by its electrochemical reduction stability, ${ }^{49}, 50$ but also by the cyclic framework in which it 5 is contained, and the nature (charge, size, etc.) of the associated substituents. ${ }^{51,52}$

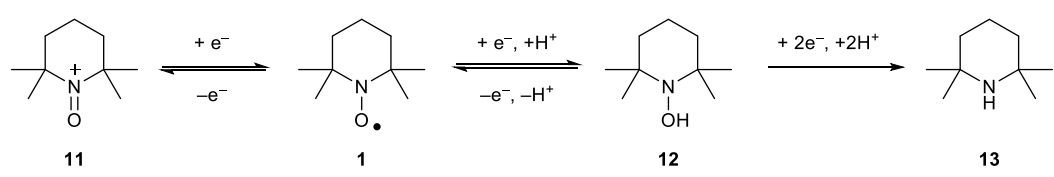

Scheme 1: The nitroxyl radical is susceptible to redox reactions.

The stability of nitroxyl radicals to reduction is often assessed using the biologically-relevant ascorbic acid as a reducing agent, albeit this is only a simple 10 model for the various processes and differing reducing environments that may be encountered in cells. ${ }^{52-54}$ Through comparison of susceptibility to ascorbate, some general properties of nitroxides have been identified which improve the resilience of the radical in reducing environments. The first of these is that five-membered ring nitroxides are significantly more stable towards reduction than six..$^{51,55,56}$ This is

15 likely a consequence of the change in hybridisation of the nitrogen atom that occurs on reduction, where torsional strain is relieved on going from $\mathrm{sp}^{2}$ to $\mathrm{sp}^{3}$ hybridisation for six-membered rings, but increases for five-membered rings. Inductive effects of susbtituents on the ring can also play a role, particularly for substituted pyrrolinoxyl radicals. ${ }^{49}, 51,57$ An approximate order of stability is 20 illustrated in Figure 4.

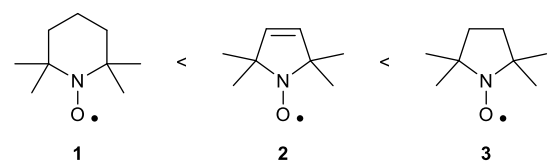

Figure 4: The stability of nitroxyls towards reduction correlates with the size and nature of the nitroxyl-bearing ring.

The second general stabilising effect is that of increasing the steric bulk of the ${ }_{25}$ flanking alkyl substituents which shield the radical from reduction, or stabilise it relative to the hydroxylamine where an equilibrium exists. ${ }^{57}$ For example, the tetraethyl-substituted isoindolinyl nitroxide has been shown to be highly resistant to ascorbic acid reduction, and its stability was further enhanced when bound to the ribose of RNA via a thiourea linker (14, Figure 5). ${ }^{58}$ The enhanced stability of the 30 PROXYL framework can be combined with such steric protection to give particularly stable radicals: the tetraethyl-flanked PROXYL (15) remains $\sim 90 \%$ intact after two hours exposure to ascorbate or frog oocyte cells / cell extract. ${ }^{52,59}$ Bis(spirocyclohexyl) groups flanking the nitroxyl (16) also confer stability against bioreduction, although to a lesser extent than tetraethyl substituents. This is likely ${ }_{35}$ due to less effective steric shielding for a cyclohexane ring compared to the more mobile ethyl groups. ${ }^{53,57,59,60}$ However, some spirocyclic systems can confer remarkable stability: the fully substituted PROXYL (17) was found to be exceptionally resistant to ascorbic acid reduction. ${ }^{61}$

4 | [journal], [year], [vol], 00-00 


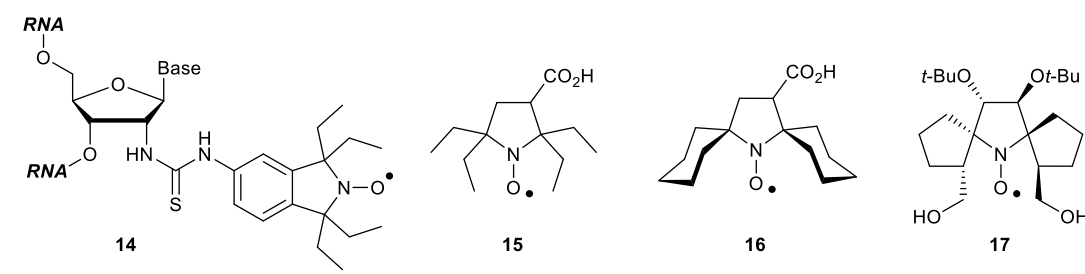

Figure 5: Nitroxide frameworks shown to be particularly stable towards reduction.

One caveat in label design is that many of these extended alkyl chains increase label hydrophobicity, which may cause problems for some labelling strategies, or 5 unwanted sample aggregation. ${ }^{62}$ The electronic influence of substituents can also affect stability, and a careful consideration of both steric and electronic effects is therefore required when designing labels. ${ }^{50}$

\subsection{Use of nitroxides in DEER}

The pulsed EPR experiment known as double electron-electron resonance (DEER), 10 or pulsed electron double resonance (PELDOR), has become a useful method for measuring nanometre distances between pairs of nitroxides. ${ }^{1,3,63-65}$ The popularity of this experiment in bis-nitroxide systems originates from its use of two microwave frequencies, which allows much of the nitroxide spectrum to be measured under common hardware limitations: the spectral width of the nitroxide is about $180 \mathrm{MHz}$ 15 at X-band frequency, and about three times that at W-band, whereas $\pi$ pulse lengths are typically greater than $10 \mathrm{~ns}$. The 4-pulse DEER experiment measures the dipolar coupling frequency as a modulation on a refocused echo. ${ }^{66,67}$ The DEER measurement needs to be set up such that the dipolar frequency can be measured accurately, which means that the echo must have a good signal-to-noise ratio (SNR) 20 with the appropriate DEER inter-pulse delays (i.e. time window). The SNR can be improved by repeating the experiment and averaging results. The repetition rate is optimal when the echo is approximately more than $70 \%$ recovered, at $1.2 \times \mathrm{T}_{1}$ (longitudinal relaxation time), where $T_{1}$ values are typically on the order of one millisecond. ${ }^{68}$ The time window is dependent upon the spin coherence time $\left(\mathrm{T}_{\mathrm{m}}\right)$ of 25 the spin label. It is often shortest for samples with high local or global concentration, as has been explored for spin-labelled proteins in lipid membranes. ${ }^{65}$, ${ }^{69}$ Relaxation due to instantaneous diffusion can be reduced by working at as low concentrations as feasible and through careful choice of pulse lengths in experiments such as DEER. ${ }^{65}$ For the 5- and 6-membered nitroxides with tetramethyl groups

30 flanking the radical, this balance between the $T_{1}$ and $T_{m}$ relaxation times is often optimal at around $50 \mathrm{~K} .^{65}$

A typical soluble spin-labelled biomolecule would have a $\mathrm{T}_{\mathrm{m}}$ time of $2-3 \mu \mathrm{s}$ and this would allow for a time window of ca. $3 \mu$ s which corresponds to the accurate measurement of a $3 \mathrm{~nm}$ distance, assuming a single Gaussian distribution with a 35 standard deviation of $0.2 \mathrm{~nm}$. However, it has been found that using deuterated solvent and cryoprotectant significantly lengthens the $\mathrm{T}_{\mathrm{m}}$ time since the ${ }^{2} \mathrm{H}$ nuclei have a lower magnetic moment than ${ }^{1} \mathrm{H}$, and this reduces the rate of relaxation through spin diffusion. ${ }^{70-72}$ The loss through spin diffusion can also be reduced by using more advanced DEER pulse sequences, e.g. 5-pulse DEER. ${ }^{73}$ Further, Norman 40 and co-workers have shown that deuteration of the molecule the spin label is attached to, in their case a protein, reduces the contribution from this relaxation mechanism to such an extent that distances over $14 \mathrm{~nm}$ can be measured accurately.,

[journal], [year], [vol], 00-00 |5 
74, 75 Interestingly, isotope substitution of the protons on the gem-dimethyl substituents does not extend the relaxation time. ${ }^{65}$ Conversely, in CW EPR where distances over $1 \mathrm{~nm}$ are assessed by the dipole-dipole broadening on the spectral linewidth, it has been shown that deuteration of the label increases the upper ${ }_{5}$ measureable distance from $2 \mathrm{~nm}$ to about $2.5 \mathrm{~nm}^{76}$ The alternative isotope substitution of ${ }^{15} \mathrm{~N}$ at the nitroxyl moiety has been applied to interesting effect to allow orthogonal labelling using two, or more, nitroxide spin labels: this makes use of the two microwave frequencies used in DEER, and indeed its $\mathrm{CW}$ predecessor ELDOR, and the only partial spectral overlap between the ${ }^{15} \mathrm{~N}(\mathrm{I}=1 / 2)$ and ${ }^{14} \mathrm{~N}(\mathrm{I}=$ 10 1) EPR lineshapes. ${ }^{77,78}$

The lower distance limit in the DEER experiment is determined by the requirement that the bandwidth of both sets of pulses can excite the full dipolar lineshape. In practice this has set the lower limit at approximately $1.5 \mathrm{~nm}$. $^{3,79}$ The DEER experiment itself only requires that the labelled molecule does not tumble fast 15 enough to average out the dipole-dipole coupling between the spin labels. ${ }^{80}$ Thus, if the spin labels can be optimised such that their relaxation rates are favourable for measurement at higher temperatures, then tethered or otherwise immobilised molecules could be used. This would open up the possibility of measurement at or near physiological temperatures. ${ }^{81,82}$

20 The DEER technique is capable of extracting distances and their distributions with nanometre accuracy, and also orientational information between the labels when the nitroxide spin labels have a well-defined, narrow distribution of conformations with respect to one another. ${ }^{83-87}$ The likelihood of this occurring is increased if the label is conformationally restricted through either steric bulk, or

25 linker restriction. However, it is important that disruptions to the material are minimal, and that the label can be used in a facile manner through simple and efficient labelling procedures.

The conformations and dynamics of some spin labels attached to biomolecules, particularly methanethiosulfonate (MTS, 18, Figure 6), have been investigated 30 experimentally through EPR analysis and crystallography, and computationally by several groups. ${ }^{88-102}$ Importantly, there is software freely available to enable users to label their target in silico and calculate the most probable conformations, since the conformation of the spin label tether must also be considered when interpreting DEER measurements. ${ }^{103-108}$

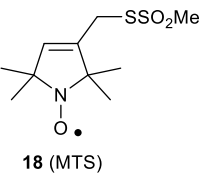

Figure 6: Structure of the methanethiosulfonate (MTS) nitroxide spin label.

\subsection{Spin relaxation rates}

The DEER experiment relies on measuring the dipolar coupling frequency between the spin labels, which increases as $r^{-3}$ where $r$ is the distance between the radicals. ${ }_{40}$ Hence, the measurement of relatively long distances requires the spin labels to have long spin coherence times, which also increases the concentration sensitivity of the experiment for a given dipolar frequency. Nitroxide spin label measurements are usually carried out at $50 \mathrm{~K}$, and enhancing spin coherence times could enable measurements at higher temperatures (i.e. liquid nitrogen, rather than the expensive

6 | [journal], [year], [vol], 00-00

This journal is $\odot$ The Royal Society of Chemistry [year] 
liquid helium currently required by laboratories not equipped with a closed-circuit cryostat). Ultimately, measuring DEER at higher temperatures, perhaps even physiological temperatures, would provide valuable structural information for many systems.

5 As the temperature of measurement increases, $\mathrm{T}_{1}$ will decrease in a manner dependent on the structure the spin label, the degree of spin orbit coupling and the nature of the solvent. ${ }^{109}$ At $50 \mathrm{~K}$, tetramethylpyrrolinoxyl spin labels such as MTS (18, Figure 6), have optimal relaxation times for the DEER experiment; other nitroxide frameworks either match these relaxation times, or compare unfavourably

10 to the pyrroline structure. For methyl-flanked nitroxyl radicals, as temperatures increase above $\sim 70 \mathrm{~K}$, the adjacent methyl groups begin to rotate at a rate comparable to the hyperfine anisotropy, which provides a route for dephasing (Figure 7). Higher aliphatic groups (such as ethyl) are expected to provide a similar relaxation mechanism, albeit with a different energy barrier. ${ }^{109}$ However, adjacent 15 cyclic groups (i.e., bis(spirocyclic) nitroxides) cannot undergo this rapid rotation and consequent modulation of field; the $T_{m}$ for these nitroxides decreases much more slowly with increasing temperature, as other motions are able to modulate $g$ and $A$ anisotropy. ${ }^{110,111}$ As the glassy solvent matrix softens and eventually melts, the echo dephasing is dominated by motional processes. ${ }^{109}$
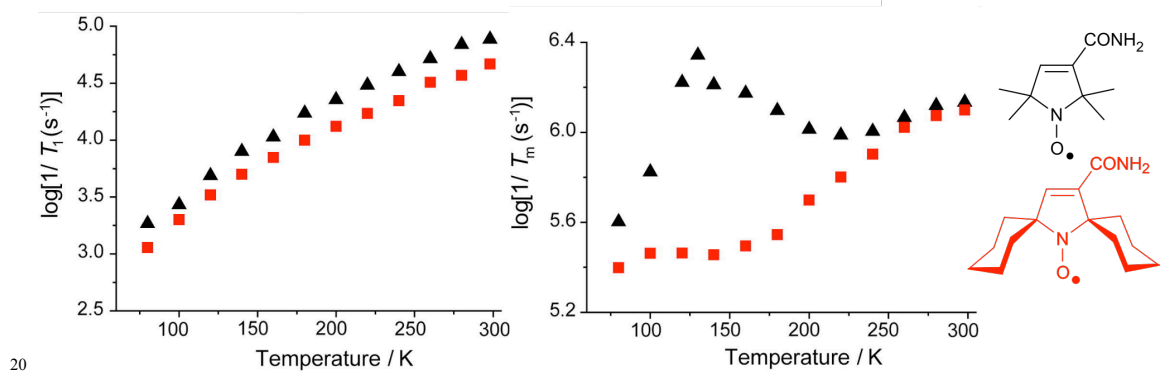

Figure 7: The temperature dependence of $\mathrm{T}_{\mathrm{m}}^{-1}$ and $\mathrm{T}_{1}{ }^{-1}$ for tetramethyl- (black) and bis(spirocyclohexyl)-substituted (red) pyrrolinoxyls. Image modified and reprinted from Ref. 112 with permission from Elsevier.

Despite the above properties, spirocyclic groups do not appreciably increase $T_{m}$ ${ }_{25}$ relative to gem-dimethyl-containing nitroxides when measured at ambient temperatures in trehalose (Figure 7) ${ }^{82}$ However, a spirocyclohexyl-iodoacetamidoTEMPO label (see 19, Figure 9) attached to T4L allowed for an ambient temperature DEER measurement of $3.2 \mathrm{~nm}$ to be taken, whereas MTS (18) did not. ${ }^{81} \mathrm{~A}$ similar effect was found for labelled DNA immobilized in trehalose. ${ }^{82}$ Therefore, just as for 30 free labels, the interaction between the label and its environment is important for determining $\mathrm{T}_{\mathrm{m}} \cdot{ }^{111}$ This effect will be crucial to allowing DEER experiments to be made at physiological temperatures.

\section{Synthetic routes to nitroxide spin labels}

\subsection{Synthesis of nitroxyl radicals}

${ }_{35}$ A prerequisite for the synthesis of any spin label is the installation of the nitroxyl functionality itself. This is most commonly achieved through oxidation of the corresponding secondary amine, for which a variety of oxidants can be used

[journal], [year], [vol], 00-00|7 
(Scheme 2). The most popular method involves treatment of the amine 20 with excess $\mathrm{H}_{2} \mathrm{O}_{2}$ and a catalytic amount (typically $15-20 \mathrm{~mol} \%$ ) of $\mathrm{Na}_{2} \mathrm{WO}_{4} \cdot{ }^{13}$ Although frequently employed, the high polarity of the solvent needed to solubilize the catalyst (usually water/ethanol mixtures) can lead to poor substrate solubility for ${ }_{5}$ lipophilic spin labels, and consequent long reaction times and/or low conversion. ${ }^{113}$ The mechanism of this process involves oxidation of $\mathbf{2 0}$ to the hydroxylamine $\mathbf{2 1}$, which is further oxidised by the relatively strong tungsten(VI) oxidant to oxoammonium salt 22 (Path A). This salt is in turn able to oxidize $\mathrm{H}_{2} \mathrm{O}_{2}$ to $\mathrm{O}_{2}$, itself being reduced to the nitroxyl $\mathbf{2 3}$, or can react with residual hydroxylamine $\mathbf{2 1}$ to 10 form two molecules of nitroxyl radical 23 (Path B). ${ }^{114}$ Pre-formed hydroxylamines may also be oxidised to the nitroxyl by mild oxidants such as $\mathrm{MnO}_{2}$ or $\mathrm{NaNO}_{2}$ (Path C) ${ }^{59,} 115$ this latter oxidation can even proceed spontaneously in the presence of atmospheric oxygen under neutral or basic conditions. ${ }^{13}$

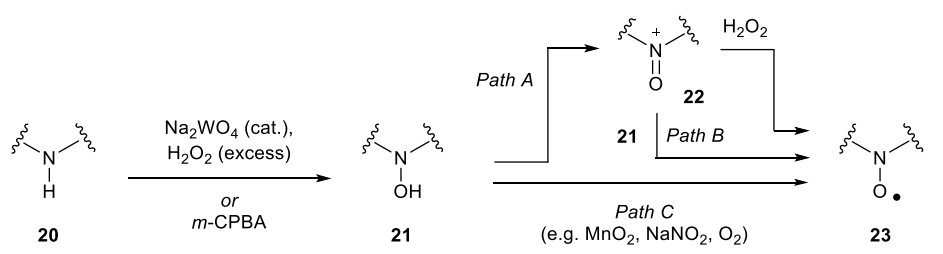

15

Scheme 2: Methods for the preparation of nitroxyls.

An alternative method for amine oxidation employs 1.5-2 equivalents of $m$ CPBA. ${ }^{116,117}$ This reagent often results in a rapid and high-yielding oxidation, which likely proceeds via path B in Scheme $2{ }^{118}$ It is tolerant of other functional groups: for example, the double bond of pyrroline 24 (Scheme 3) was unaffected during 20 nitroxyl formation (25). ${ }^{119}$ One cautionary note in all of these oxidations is that the oxoammonium salt 22 (formed in both the $\mathrm{Na}_{2} \mathrm{WO}_{4} / \mathrm{H}_{2} \mathrm{O}_{2}$ and $m$-CPBA methodologies) has been observed to effect oxidation of alcohols, as in the oxidation of aminoalcohol 26 to a mixture of nitroxyl alcohol 9 and ketone $\mathbf{8}^{116,117,120}$

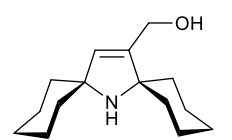

24<smiles>CC1(C)CC(O)CC(C)(C)N1</smiles>

26

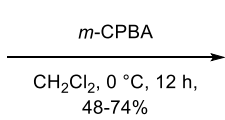

$48-74 \%$

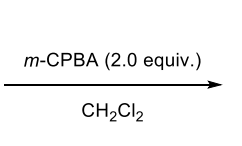

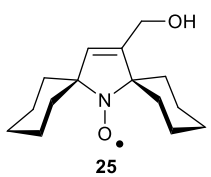

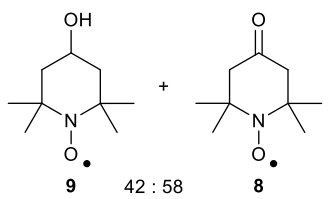

25

Scheme 3: $N$-Oxidation by $m$-CPBA, and functional group tolerance.

Due to the potential susceptibility of nitroxyls to reduction or oxidation during chemical synthesis or under biological conditions, several interesting protection strategies have been employed that allow a late-stage deprotection of the nitroxyl itself. This includes the use of an $O$-methyl hydroxylamine derivative 27 (Figure 8), 30 a robust functionality from which the nitroxyl can be revealed on treatment with $\mathrm{m}$ CPBA. ${ }^{121}$ An elegant photolabile protecting group strategy has also been developed, where irradiation of $\mathbf{2 8}$ at $405 \mathrm{~nm}$ delivers the nitroxyl in high yield (92\%). ${ }^{122}$ This

8 | [journal], [year], [vol], 00-00

This journal is (c) The Royal Society of Chemistry [year] 
latter chemistry has been applied to a masked nitroxyl attached to a DNA oligonucleotide at cytidine.

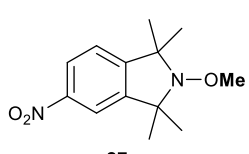

27

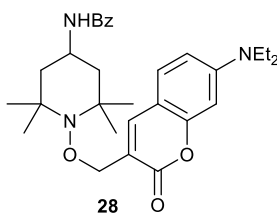

280

Figure 8: Masked nitroxyl radicals.

\section{3.2 Synthesis of piperidinyl (TEMPO) nitroxides}

2,2,6,6-Tetramethyl-4-piperidone (29, Scheme 4) is ubiquitous as a starting material for the synthesis of the frequently used TEMPO spin labels. ${ }^{13}$ Straightforward functional group interconversions (FGIs) lead to a wide variety of functionalized 2,2,6,6-tetramethylpiperidines (30, see discussion below).

10 An important and convenient method to transform 29 into 2,6-bis(spirocyclic) piperidones $31\left(\mathrm{Y}=\mathrm{CH}_{2}, \mathrm{O}, \mathrm{C}=\mathrm{O}, \mathrm{SO}_{2}, \mathrm{NAc}\right.$, etc.) uses a phase-transfer catalyst to effect a formal exchange of acetone for ketone 32. ${ }^{123}$ This chemistry provides access to spirocyclic piperidine spin labels 33, many of which have been found to exhibit enhanced phase memory times in EPR experiments due to the restricted rotational 15 freedom imparted by the spirocyclic ring system. ${ }^{110}$ When $\mathrm{Y}=\mathrm{S}$, reductive cleavage of the $\mathrm{C}-\mathrm{S}$ bonds with Raney nickel leads to the tetraethyl-substituted spin label $\mathbf{3 4}$, which offers improved steric shielding of the nitroxyl. ${ }^{59,123}$

Whilst this ketone exchange methodology is procedurally simple and highly effective for the synthesis of spirocycle-containing spin labels, an alternative 'de 20 novo' route to all three piperidine-derived nitroxides involves a double HornerWadsworth-Emmons reaction of bisphosphonate 35 to generate an intermediate dienone 36, which is a substrate for double aza-Michael addition of ammonia. This method has been used to prepare tetraethyl-substituted ketone and alcohol nitroxides (34, $\mathrm{X}=\mathrm{O}$ or $\mathrm{OH}$, respectively). ${ }^{124} \mathrm{~A}$ similar route has been used to prepare a ${ }_{25}$ bis(spirocyclohexyl)ketone $\left(\mathbf{3 3}, \mathrm{X}=\mathrm{O}, \mathrm{Y}=\mathrm{CH}_{2}\right){ }^{125}$

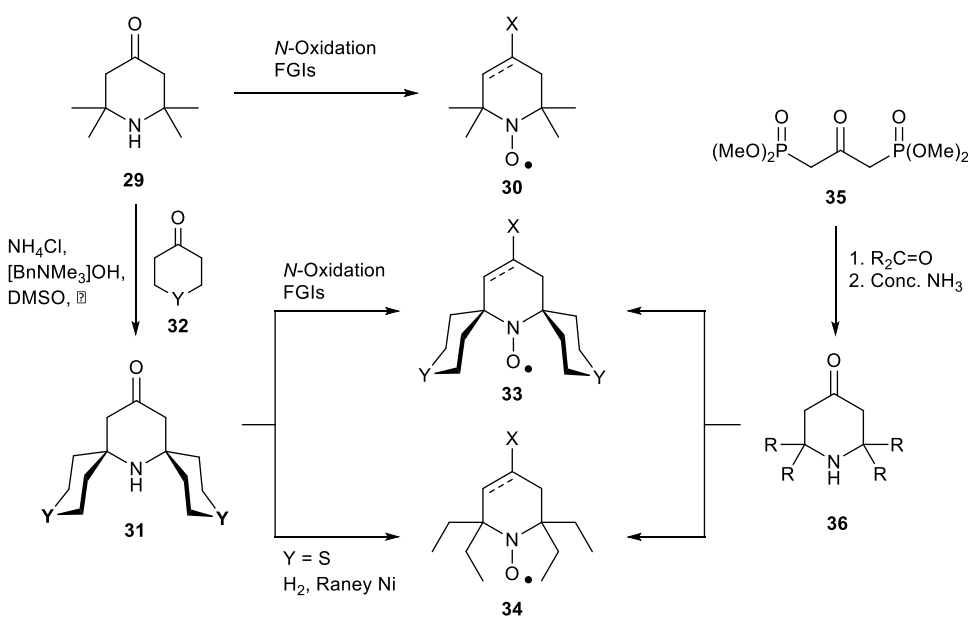

Scheme 4: General synthetic routes to 6-membered ring piperidinyl spin labels.

[journal], [year], [vol], 00-00|9

This journal is @ The Royal Society of Chemistry [year] 
The substituent at the 4-position of the piperidine ring in $\mathbf{3 0 , 3 3}$ and $\mathbf{3 4}$ is easily functionalized to prepare the spin label for attachment to target systems of interest (Scheme 5). N-Oxidation of ketone 29, followed by addition of trimethylsilyl acetylide, and subsequent dehydration and desilylation, leads to enyne nitroxide $\mathbf{3 7}$ 5 which is primed for CuAAC click reactions ${ }^{126}$ or Sonogashira cross-coupling. ${ }^{127-130}$ Alternatively, reduction of the ketone to an alcohol, conversion to a leaving group, and nucleophilic substitution by azide affords the complementary CuAAC azide partner 38. ${ }^{131}$ Amine 39, which is suitable for target labelling by methods such as amide formation ${ }^{132}$ or alkylation, ${ }^{127,133-137}$ can be installed by reductive amination 10 with ammonia. ${ }^{138} 39$ can also be converted to isocyanate $\mathbf{4 0}$ or thioisocyanate $\mathbf{4 1}$ on treatment with diphosgene or thionyl chloride, respectively; ${ }^{139,}{ }^{140}$ these spin labels undergo reaction with amines (thio)urea-linked spin labels. ${ }^{139,}{ }^{141}$ Ketone 29 may also be transformed into acid $\mathbf{4 2}$ on treatment with tosylmethyl isocyanide (TosMIC), followed by hydrolysis of the intermediate nitrile. ${ }^{142} 42$ in turn can be 15 used directly as labelling agent, or converted into an activated carboxylate such as the $N$-hydroxysuccinimide ester $\mathbf{4 3}{ }^{143}$

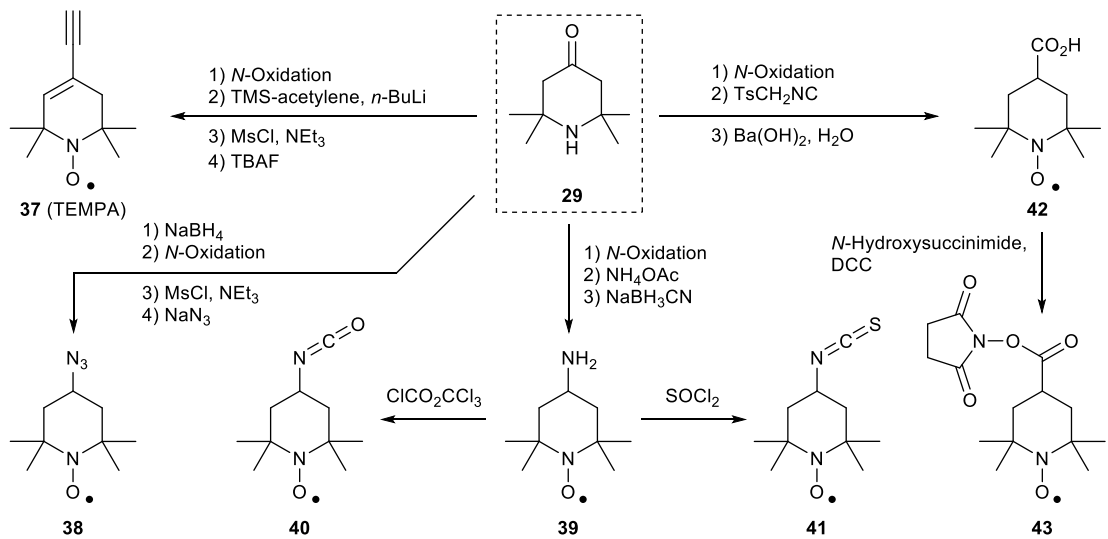

Scheme 5: Structures and syntheses of commonly used piperidinyl spin labels.

For tetraethyl- or bis(spirocyclohexyl)-substituted piperidinyl nitroxides, ${ }_{20}$ comparatively few labelling functionalities (X) have been reported (Figure 9). Although tetraethyl derivatives such as $\mathbf{4 4}^{52}$ and spirocyclic amine $\mathbf{4 5}^{6,144,145}$ have been synthesized, they have not to date been used for spin labelling. Iodoacetamide 19 has recently been used to spin label T4 lysozyme and perform DEER measurements at room temperature. ${ }^{146}$ Azide 46 was recently reported by our ${ }_{25}$ groups, and was used to label nucleic acids in a CuAAC spin-labelling strategy. ${ }^{147}$
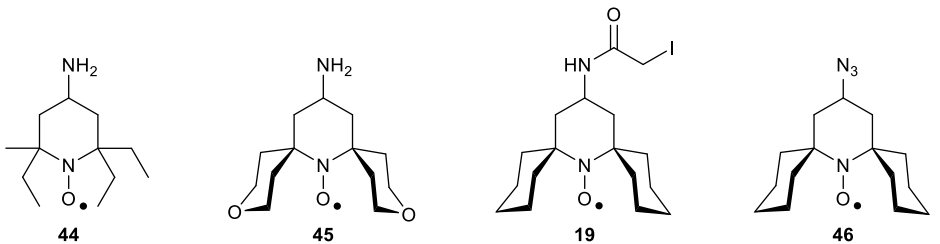

Figure 9: Tetraethyl- and bis(spirocyclohexyl)-substituted TEMPO derivatives.

10 | [journal], [year], [vol], 00-00 


\subsection{Synthesis of pyrrolidinyl and pyrrolinyl (PROXYL) nitroxides}

5-Membered ring 2,2,5,5-tetrasubstituted pyrrolidinyl (PROXYL) nitroxides can, as mentioned, benefit from improved stability towards reducing conditions compared to their 6-membered ring cousins, and as such enjoy much popularity. However, it is 5 worth noting that substituted PROXYLs are generally synthesised as racemates, and thus are likely to give rise to a mixture of diastereomers on labelling biomolecules.

The unsaturated 3-pyrroline scaffold is most conveniently accessed from the corresponding piperidones $\left(\mathbf{4 7}\right.$, Scheme 6) via an initial double $\left(\alpha, \alpha^{\prime}\right)$ bromination. ${ }^{148}$ To avoid decomposition pathways such as transannular nucleophilic 10 substitution to give an aziridine, the intermediate dibromide $\mathbf{4 8}$ is typically isolated as a hydrobromide salt. Exposure to basic conditions (e.g. hydroxide, methoxide, or ammonia) effects a Favorskii rearrangement, followed by in situ elimination of $\mathrm{HBr}$, to give the 3 -substituted pyrroline carboxylic acid derivatives $49 .{ }^{149}$ Oxidation to the nitroxyl can be followed by any necessary functional group manipulations to convert 15 these Favorskii-derived carboxylic acid derivatives to the various spin labels of the pyrroline family (50, see below for examples).

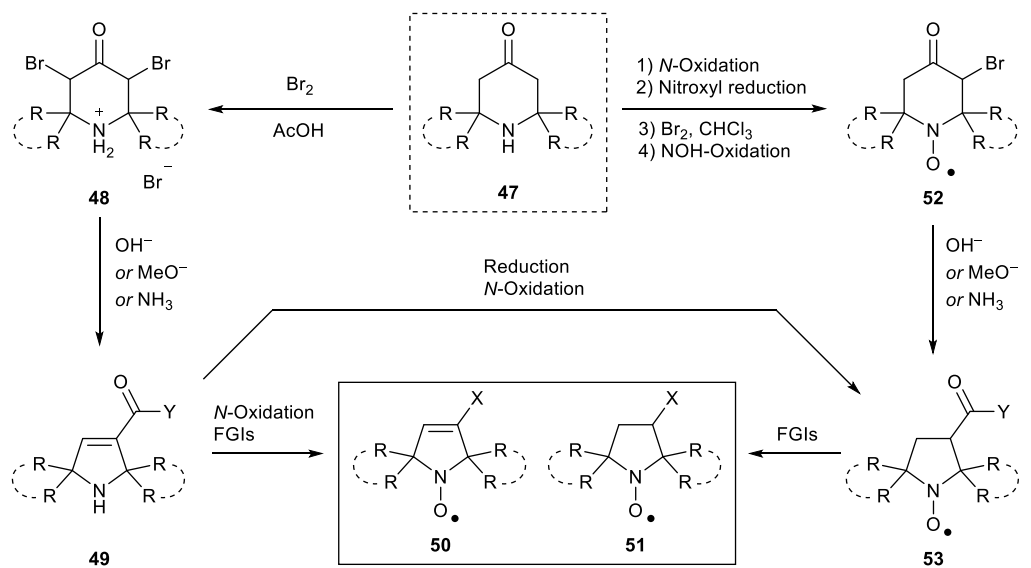

Scheme 6: General synthetic routes to pyrrolinyl and pyrrolidinyl nitroxides.

The related saturated pyrrolidine nitroxides (often nicknamed 'PROXYLs') $\mathbf{5 1}$ 20 (are synthesised via a similar route, this time through monobrominated ketone $\mathbf{5 2}$. $^{57}$, 59,115 Here, the secondary amine is first 'protected' as a hydroxylamine, which prevents the aforementioned aziridine formation. However, as oxidation is difficult to stop at the hydroxylamine stage, a nitroxyl radical is first formed, which is then reduced to the hydroxylamine. After Favorskii rearrangement and oxidation, the ${ }_{25}$ pyrrolidine nitroxide derivatives $\mathbf{5 3}$ can be functionalised as desired (51, see below for examples). Pyrrolidine carboxylic acid derivatives $\mathbf{5 3}$ have also been formed by reduction of the corresponding pyrrolines 49 with $\mathrm{H}_{2}$ and $\mathrm{Pd} / \mathrm{C} .{ }^{149}$ As the nitroxyl radical is also at risk of reduction in this step, it is generally performed before $N$ oxidation (however, $\mathrm{LiBH}_{4}$ has recently been shown to reduce the double bond of an 30 amide pyrrolinyl nitroxide without affecting the radical or carbonyl). ${ }^{150}$

Syntheses of some commonly used 5-membered nitroxide spin labels are shown in Scheme 7. Several derivatives are prepared from initial reduction of the carboxylic acid sidechain (49) to allylic alcohol 54, a key intermediate that has been transformed into many labelling groups. If carried out after $N$-oxidation, carboxylic

[journal], [year], [vol], 00-00|11 
acid reduction has been found to be challenging, ${ }^{151}$ as competing conjugate reduction and/or reduction of the nitroxyl can be observed. Our groups have recently found that $N$-oxidation and subsequent reduction of the methyl ester $(49, \mathrm{Y}=\mathrm{OMe})$ with DIBALH at $-50{ }^{\circ} \mathrm{C}$ effects a clean and high-yielding reduction to $\mathbf{5 4}$, avoiding 5 these side reactions. ${ }^{147}$ Alternatively, acid derivatives $\mathbf{4 9}$ may be reduced before $N$ oxidation, the latter process being tolerant of the resultant allylic alcohol. ${ }^{119}$

From alcohol 54, iodide $\mathbf{5 5}$ is prepared by mesylation and Finkelstein reaction. ${ }^{152}$ Alcohol 54 has also been converted to methanethiosulfonate MTS (18), a popular spin label for the functionalisation of cysteine residues in peptides (see below for 10 applications). ${ }^{153}$ Alternatively, $\mathbf{5 4}$ can be transformed into azide $\mathbf{5 6}$ by mesylation and substitution. ${ }^{154}$ Enyne $\mathbf{5 7}$ (known as TPA) is another popular spin label which is readily prepared from aldehyde $\mathbf{5 8}^{148,}{ }^{155}$ by Ohira-Bestmann alkynylation, ${ }^{156}$ or other alkyne-forming methods. ${ }^{157}$ The saturated carboxylic acid $\mathbf{5 3}$ (or derivatives) also serve as useful precursors to labelling functionalities. For example, $N$ 15 hydroxysuccinimide ester $\mathbf{5 9}$ has been synthesized from $\mathbf{5 3}(\mathrm{Y}=\mathrm{OH})$ by diimidemediated esterification. ${ }^{158}$ Amine $\mathbf{6 0}$ is available via a Hofmann rearrangement of the amide $\mathbf{5 3}\left(\mathrm{Y}=\mathrm{NH}_{2}\right){ }^{13}$ this spin label can be further derivatised to labels such as iodoacetamide $\mathbf{6 1}$ (by acylation and iodination) ${ }^{159}$ or the Michael-acceptor maleimide 62. ${ }^{160}$

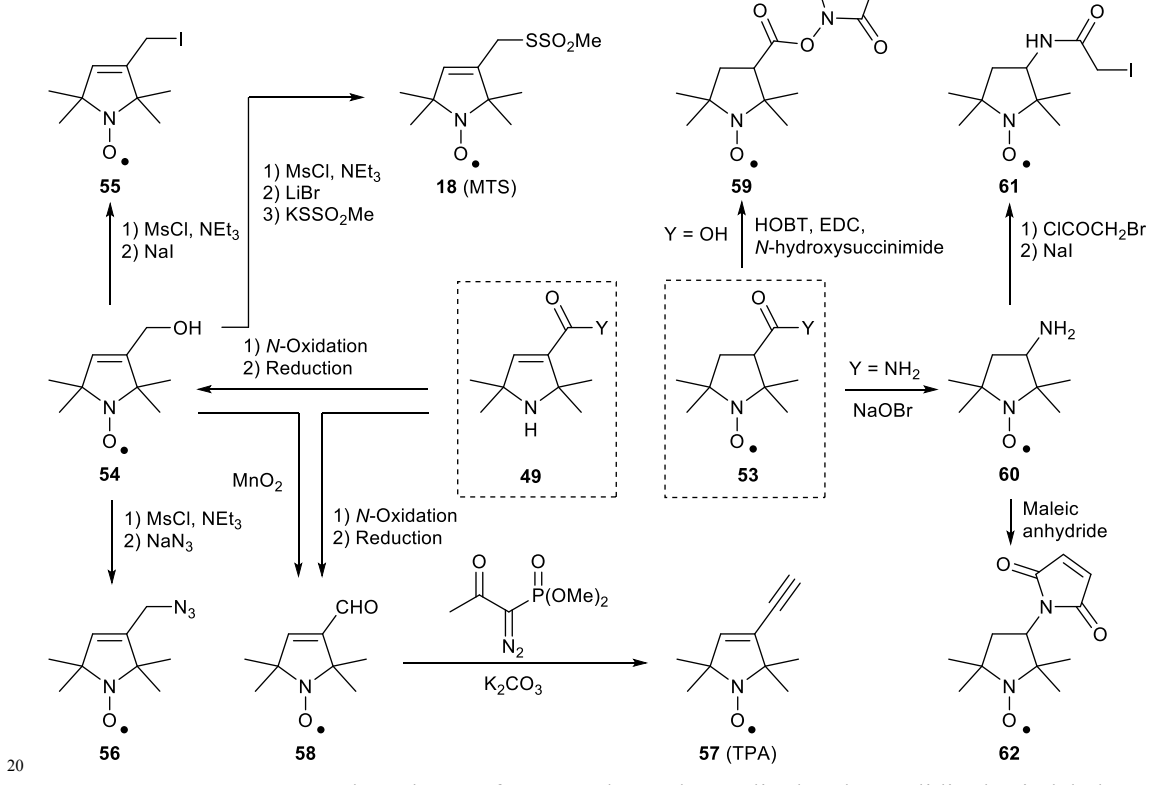

Scheme 7: Structures and syntheses of commonly used pyrrolinyl and pyrrolidinyl spin labels.

A number of bis(spirocyclohexyl)-substituted pyrrolinyl and pyrrolidinyl labels have been prepared (Figure 10). For the spirocyclic nitroxides, $N$ hydroxysuccinimide esters are known for both the saturated ${ }^{161}$ and unsaturated ${ }^{119,150}$ 25 -membered rings (63), prepared in analogy to their tetramethyl relatives (see 59, Scheme 7), as have the methanethiosulfonate $\mathbf{6 4}^{150}$ and azide $\mathbf{6 5} .^{147}$ Other variants include isocyanate $\mathbf{6 6}$, accessed by treatment of the unsaturated ester $\mathbf{6 3}$ with $\mathrm{NaN}_{3}$ followed by a Curtius rearrangement, ${ }^{162}$ and two spirocyclic amino acid derivatives

12 | [journal], [year], [vol], 00-00 
(67 and 68). ${ }^{119}$ Several tetraethyl-substituted pyrrolinyl and pyrrolidinyl nitroxides are also known: examples include amino acid derivatives 69 and 70, and $N$ hydroxysuccinimide esters 71, prepared in analogy to their spirocyclic counterparts. ${ }^{119}$ The latter have been found to be highly stable to reduction.

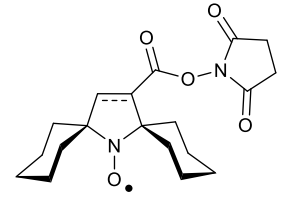

63

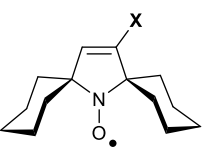

64: $\mathrm{X}=\mathrm{CH}_{2} \mathrm{SSO}_{2} \mathrm{Me}$ 65: $\mathrm{X}=\mathrm{CH}_{2} \mathrm{~N}_{3}$

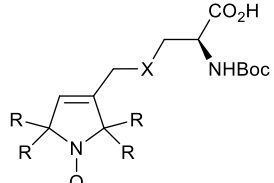

0 .

67: $\mathrm{X}=\mathrm{S}, \mathrm{R}=\left(\mathrm{CH}_{2}\right)_{5}$

68: $X=\mathrm{NH}, \mathrm{R}=\left(\mathrm{CH}_{2}\right)_{5}$

69: $\mathrm{X}=\mathrm{S}, \mathrm{R}=\mathrm{Et}$

70: $\mathrm{X}=\mathrm{NH}, \mathrm{R}=\mathrm{E}$<smiles>CCC1(CC)C=C(C(=O)ON2C(=O)CCC2=O)C(CC)(CC)N1O</smiles>

71

Figure 10: Bis(spirocyclohexyl)- and tetraethyl-substituted pyrrolinyl and pyrrolidinyl nitroxides.

\subsection{Synthesis of imidazolinyl, imidazolidinyl and oxazolidinyl nitroxides}

Spin labels containing additional heteroatoms in the nitroxyl-bearing ring have been synthesised through various modular de novo ring-forming routes (Scheme 8). These 10 nitroxides have the benefit of being readily adaptable to contain functional groups for label attachment (substituents X, Y). Synthetically, the hydrochloride salts of $\alpha$ hydroxylamine ketones (72) can be condensed with ketones $\mathbf{7 3}$ in the presence of ammonium acetate to obtain unsaturated imidazoline nitroxides $\mathbf{7 4}$ after oxidation of the intermediate hydroxylamine. ${ }^{82}$ These have been further $\mathrm{N}$-alkylated at the imine is nitrogen atom, and the resulting iminium ion reduced to form the saturated imidazolidine nitroxides (75). ${ }^{112}$ This chemistry has been particularly exploited in the field of protein spin labelling, due to the suitability of attachment to proteins via the residual sidechain functionalities in the spin labels.

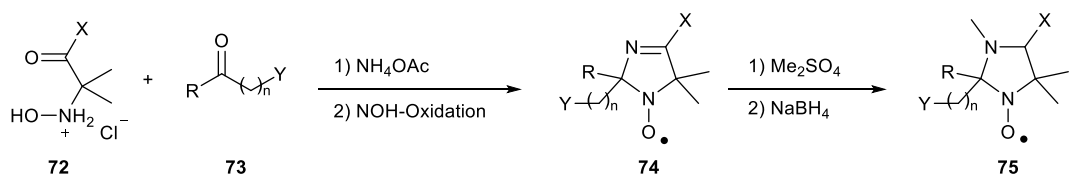

Scheme 8: Routes to spin labels containing additional heteroatoms in the nitroxyl-bearing ring.

A selection of imidazolinyl and imidazolidinyl nitroxides is shown in Figure 11, which illustrate the diversity of spin-labelling functionalities that can be installed (76-79). ${ }^{27}$ Related oxazolidine nitroxides (often termed 'DOXYLs') have also been described (80), prepared from condensation of a ketone and an aminoalcohol. ${ }^{163}$

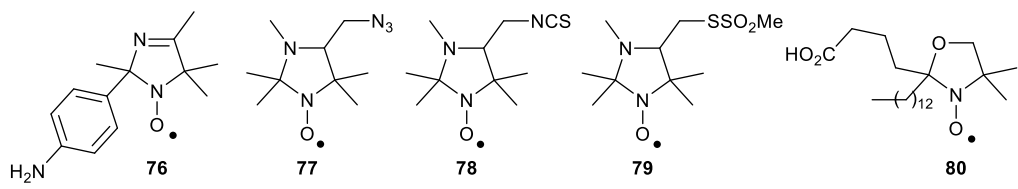

Figure 11: Structures of selected oxazolinyl, imidazolinyl and imidazolidinyl nitroxides.

\subsection{Synthesis of isoindolinyl nitroxides}

The final major structural class of nitroxide spin label in common usage is the isoindoline-derived scaffold. The most common starting point for the synthesis of 30 these derivatives is $N$-benzylphthalimide (81, Scheme 9), from which the four $\alpha$ -

[journal], [year], [vol], 00-00|13 
alkyl substituents are installed via a challenging quadruple Grignard addition. ${ }^{164}$ Bottle and co-workers recently reported an improved methodology towards these substrates, ${ }^{165}$ where the easily formed hemiaminal $\mathbf{8 2}$ was isolated from a single addition of Grignard reagent, and then resubmitted to a six-fold excess of 5 organomagnesium compound to reach the fourfold adduct. High-temperature reflux for several days in the latter step afforded tetrasubstituted isoindolines $\mathbf{8 3}$ in respectable yields; it is not clear why this procedure offers advantages over the 'onepot' approach. Following the quadruple alkylation, hydrogenolysis of the amine benzyl group and subsequent straightforward functionalisations of the aromatic ring 10 and $N$-oxidation, affords isoindoline spin label derivatives 84. The aromatic substituents can be tuned to impart aqueous solubility on the otherwise relatively lipophilic isoindoline skeleton, ${ }^{166},{ }^{167}$ and/or provide a handle for covalent attachment of the spin label.

An overview of synthetic routes toward some common or recently reported 15 isoindolinyl nitroxides is shown in Scheme 10. For the purposes of clarity, these

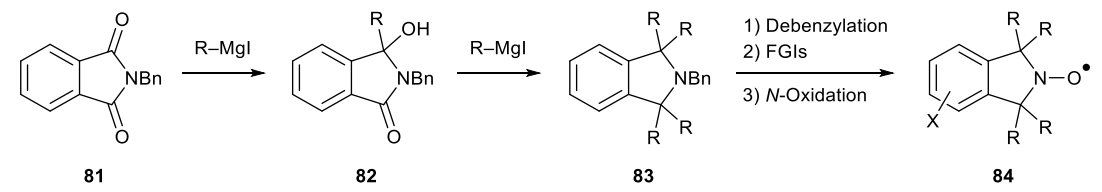

Scheme 9: General route to isoindoline-derived nitroxides.

transformations are illustrated with the parent amine, but it should be noted that $\mathrm{N}$ oxidation can be carried out at several different points in these synthetic sequences; 20 the $\mathrm{N}$-oxidation step is therefore not specified in the reaction scheme. $\mathrm{N}$-Oxidation is in general performed as the last synthetic step, as long as the oxidation conditions are tolerated by other functional groups.

Functionalisation of the parent isoindoline $\mathbf{8 5}$ is easily achieved through aromatic substitution chemistry. For example, arene carboxylation to $\mathbf{8 6}$ can be effected by ${ }_{25}$ bromination ${ }^{168,169}$ followed by cyanation and hydrolysis; ${ }^{166}$ activation of $\mathbf{8 6}$ as an $\mathrm{N}$ hydroxysuccinimide ester has been achieved through DCC-catalysed esterification. ${ }^{168}$ Amine $\mathbf{8 7}$ is a common intermediate in the synthesis of many other functionalised isoindoline nitroxides, and is prepared from $\mathbf{8 5}$ by nitration and hydrogenation of the nitro group. ${ }^{170}$ Treatment of 87 with thionyl chloride leads to 30 thioisocyanate $\mathbf{8 8}$, which can be reacted with amines to form thiourea-linked spin labels. ${ }^{171}$ Alternatively, a copper-catalysed diazo transfer reaction leads to azide 89. ${ }^{172}$ Iodide 90 can be synthesised through diazotisation and Sandmeyer reaction (or by direct iodination of the parent isoindoline $\mathbf{8 5}$ nitroxide with periodic acid); ${ }^{173}$,

17490 can further be converted into alkyne 91 by $\mathrm{Cu}$-free Sonogashira coupling, 35 followed by desilylation. ${ }^{175}$

Doubly-functionalised isoindolines have been used to create rigidified symmetrical spin-labelling systems. Aminoalcohol $\mathbf{9 2}$ has been prepared from amine 87 by diazotisation, hydrolysis to the phenol, ortho-nitration, and nitro reduction. ${ }^{176}$ Oxidative condensation of $\mathbf{9 2}$ with 5 -formyluridine followed by $\mathrm{N}$-oxidation ${ }_{40}$ provides the conformationally restricted spin-labelled uridine derivative $93 .{ }^{177}$ The related benzimidazole-tethered nitroxide uridine derivative 94 was obtained from triamine $\mathbf{9 5},{ }^{177}$ the latter prepared by nitration of $\mathbf{8 5}$, then amination through vicarious nucleophilic substitution, and nitro reduction. ${ }^{177}$ Triamine 95 has also been

14 | [journal], [year], [vol], 00-00 


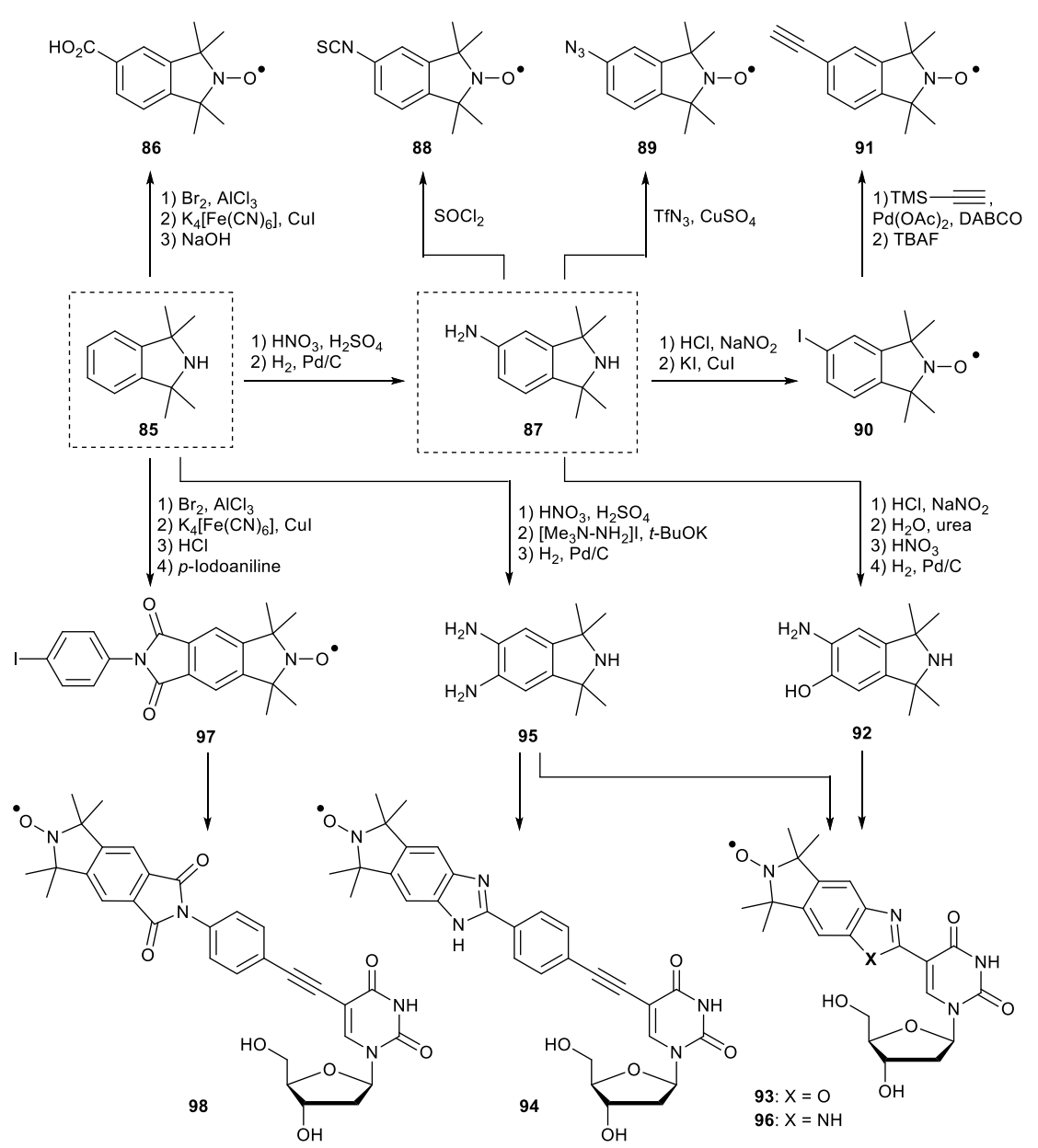

Scheme 10: Structures and syntheses of a selection of isoindolinyl nitroxides.

employed for the synthesis of $\mathbf{9 6}$ from oxidative condensation with the corresponding benzaldehyde. ${ }^{178}$ A further approach uses iodophenyl phthalimide 97, 5 which is prepared from $\mathbf{8 5}$ by a double bromination / cyanation / hydrolysis sequence, ${ }^{167,} 168$ then condensation with $p$-iodoaniline. A Sonogashira coupling strategy leads to uridine derivative $\mathbf{9 8} .{ }^{179}$

One further notable example is the cytidine analogue 99 (Scheme 11), also known as Ç, which gives highly rigid systems in the EPR spectroscopic investigation of ${ }_{10}$ nucleic acids. ${ }^{176} 99$ was synthesised from isoindoline $o$-aminophenol derivative 92 (Scheme 10) by reaction with 5-bromouridine (100) and cyclisation of intermediate bromide 101. After conversion into a phosphoramidite building block, nucleoside derivative 99 was incorporated into nucleic acids by solid-phase synthesis under modified conditions. A free nucleobase analogue of 99 (known as ç) has been ${ }_{15}$ developed using equivalent chemistry on 5-benzyl-1-bromouracil. ${ }^{180,181}$

\subsection{Bifunctional nitroxides for two-point attachment}

Nitroxide spin labels equipped with two functional groups for two-point label

[journal], [year], [vol], 00-00|15 


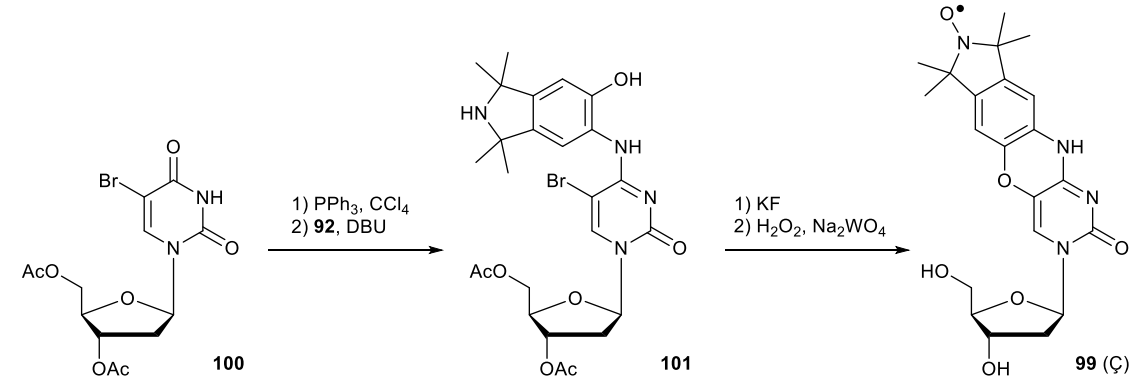

Scheme 11: Synthesis of cytidine analogue Ç.

attachment offer opportunities to construct particularly rigid systems. The two functional groups can be identical, or different, the latter potentially enabling 5 attachment of each group to a biomolecule of interest under orthogonal reaction conditions. A simple example is amino acid derivative 102 (Scheme 12), which is commonly used to label peptides. It is prepared by a Bucherer-Bergs reaction from the TEMPO ketone $\mathbf{8}$, with hydrolysis of the intermediate hydantoin and carbamoylation delivering the Fmoc-protected amino acid. ${ }^{182}$ A 2,610 bis(spirocyclohexyl) version of this spin label (103) was recently prepared from the corresponding piperidone nitroxide $\mathbf{1 0 4}$ via a similar route. ${ }^{11}$
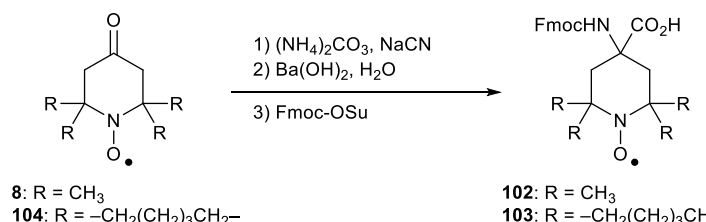

102: $\mathrm{R}=\mathrm{CH}_{3}$

102: $\mathrm{R}=\mathrm{CH}_{3}=-\mathrm{CH}_{2}\left(\mathrm{CH}_{2}\right)_{3} \mathrm{CH}_{2}-$

Scheme 12: Amino acid derivatives for two-point attachment of piperidinyl spin labels.

3,4-Bifunctionalised pyrroline spin labels are also available (Scheme 13). Many 15 of these are synthesised from diol 105, itself prepared by Michael addition of nitromethane to enoate 106, followed by a Nef reaction and reduction of the intermediate $\beta$-carboxyaldehyde. ${ }^{157}$ Double iodination/elimination of $\mathbf{1 0 5}$ affords

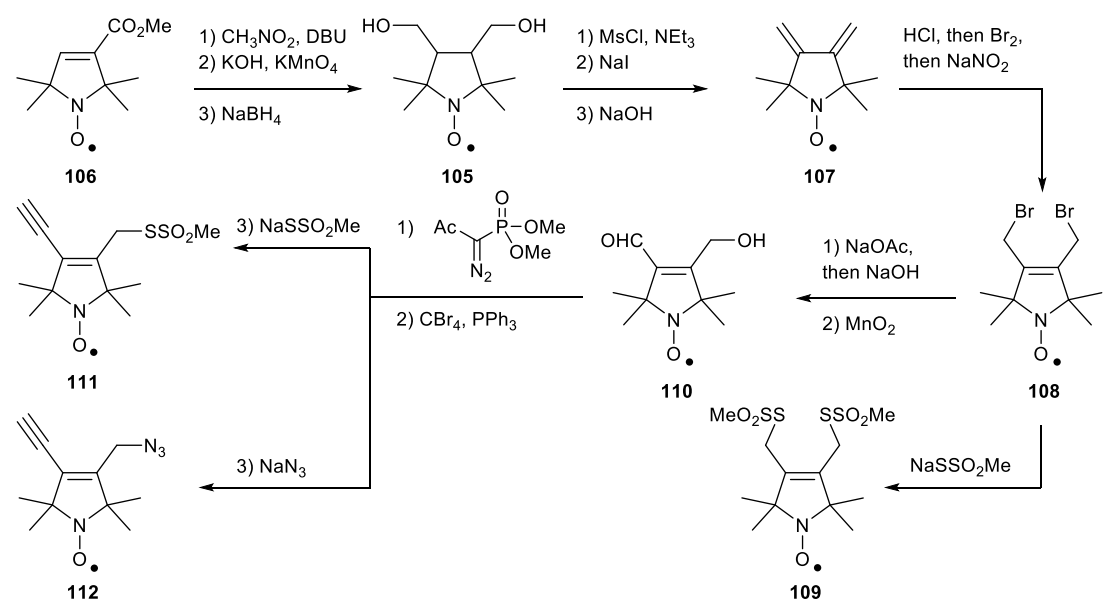

Scheme 13: Bifunctional spin labels for two-point attachment strategies.

16 | [journal], [year], [vol], 00-00 
diene nitroxide 107, which has itself been used as a starting point for numerous nitroxide derivatives (including an alternative route to the isoindoline framework). ${ }^{183} \mathbf{1 0 7}$ can be converted to 1,4-dibromide $\mathbf{1 0 8}$ on treatment with $\mathrm{Br}_{2}$, albeit this transformation requires temporary reduction of the nitroxyl to the 5 hydroxylamine, and reoxidation after bromination. Dibromide $\mathbf{1 0 8}$ can then be transformed into a selection of bifunctional spin labels: treatment with $\mathrm{NaSSO}_{2} \mathrm{CH}_{2}$ affords the symmetrical bis(methanethiosulfonate) $\mathbf{1 0 9},{ }^{157}$ whilst hydrolysis and mono-oxidation gives aldehyde 110, which can in turn be submitted to OhiraBestmann alkynylation and Appel bromination, followed conversion into 10 functionalities such as a methanethiosulfonate (111) or azide (112). ${ }^{156}$

The syntheses of the above bifunctional spin labels are rather lengthy. An alternative route to 3,4-disubstituted pyrroline nitroxides involves deprotonation of the pyrrolinyl ester 106 (Scheme 14) at the $\beta$-position with LTMP, followed by trapping with electrophiles (E) such as iodine or a chloroformate, leading to iodide $15 \mathbf{1 1 3}$ and diester 114 respectively. ${ }^{184}$ Improved access to such compounds would lead to shorter and higher-yielding routes to bifunctional nitroxides.
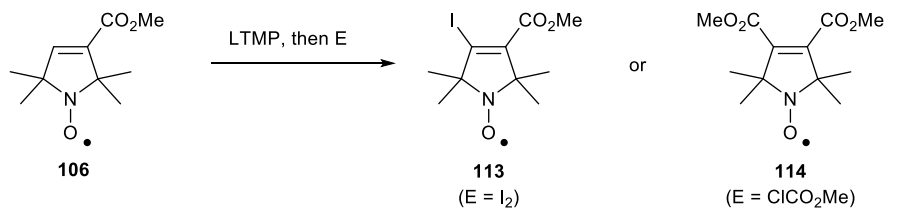

Scheme 14: Synthesis of 3,4-disubstituted pyrroline nitroxides.

\section{Recent advances in applications of spin labels}

20 The site-directed spin labelling using nitroxides at specific sites within a molecule can be achieved either through non-covalent interactions or, more usually, through covalent bond formation. Although spin labelling can be applied in many contexts (such as soft matter and surfaces), discussion in this chapter is limited to biomolecule spin labelling (proteins, oligonucleotides, lipids and sugars).

\section{${ }_{25}$ 4.1 Spin labelling of proteins}

Of the 20 universally genetically encoded amino acids, the thiol group of cysteine arguably has the most possibilities for orthogonal covalent spin labelling. For SDSL, cysteines are therefore engineered into recombinant proteins at sites of interest. The most popular label for attachment to cysteines is MTS (see 18, Scheme 7), which 30 attaches to the target by formation of a mixed disulfide with a cysteine thiol. ${ }^{153}$ Once bound to a cysteine, the complete modified disulfide-linked side chain is often referred to as R1. It provides a CW EPR spectrum that is sensitive to conformations, and may give narrow distributions in DEER due to the reasonably short linker with its restricted conformational freedom. ${ }^{47,90,98,103,105,107,185}$

35 MTS spin labelling has recently been applied to the intact E. coli cobalamin transporter BtuB outer membrane protein, which was labelled at cysteine residues external to the cell. ${ }^{186,}{ }^{187}$ Distances between R1 labels and R1 to TEMPO-labelled cyanocobalamin (TEMPO-CNCbl, 115, Figure 12), which binds to BtuB with high affinity, were measured by DEER. It was shown that conformational changes upon

${ }_{40}$ ligand binding could be followed to characterise the structure of an extracellular loop.

[journal], [year], [vol], 00-00 | 17 


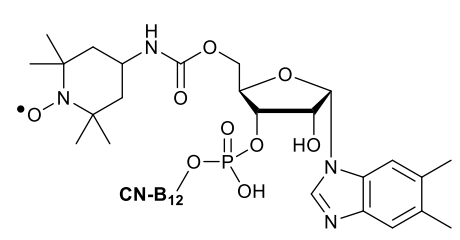

115 (TEMPO-CNCbl)

Figure 12: TEMPO-labelled cyanocobalamin.

The conformational freedom of $\mathrm{R} 1$ can be further restricted through the addition of substituents: ${ }^{184,}{ }^{188-190}$ for example, the 4-pyridyl analogue (116, Figure 13) 5 demonstrates restricted internal motion, when attached to a protein compared to R1. ${ }^{191}$ The choice of a pyridine substituent (rather than phenyl) improves label solubility, and reduces protein aggregation post-labelling. Reaction of the disulfide IDSL (117) installs an imidazolinoxyl side chain (known as V1) upon reaction with cysteine. ${ }^{88,192}$ A study found this label to have strongly hindered internal motion; 10 the authors suggest that this is due to van der Waals interactions between the disulfide and the nitrogen atom at the 3-position of the ring, but may also be due to minimization of steric interactions.

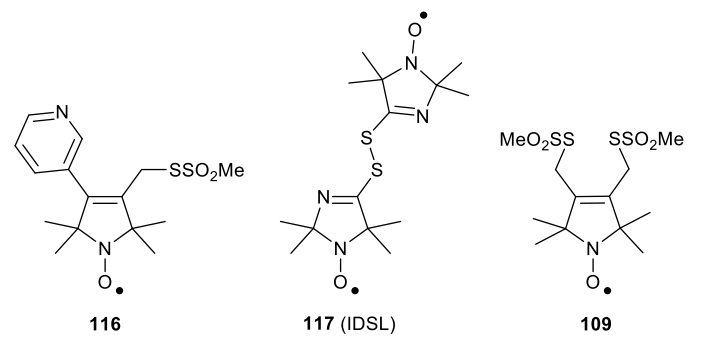

Figure 13: Structures of various disulfide bond-forming spin labels.

15 An interesting method to reduce conformational freedom is to covalently attach the spin label to two amino acids. This two-point binding strategy has been achieved using the 'double MTS' label 109 (known as 'Rx' once attached to a pair of proximal cysteines). ${ }^{89,} 190$ Due to the rigidity of the spin label, Rx reduces the distance distribution in DEER. ${ }^{84,89,193}$ More than one well-defined conformation may be

20 adopted depending upon local environment and tethering sites, and this can render orientation-selective DEER challenging. ${ }^{84}$ The reaction to form the bridged product involves titration of substoichiometric amounts of $\mathbf{1 0 9}$ to the buffered protein, and subsequent dialsysis - often extensive - to remove unbound label.

'Next generation' maleimides such as 118 and 119 (Scheme 15, synthesised in ${ }_{25}$ analogy to $\mathbf{6 2}$, Scheme 7, using mono- or dibromomaleic anhydride) may also prove useful for binding to pairs of cysteines. ${ }^{194}$ For a dibromomaleimide $(\mathbf{1 1 9}, \mathbf{X}, \mathbf{Y}=\mathrm{Br})$, a pair of proximal cysteines can substitute for both, giving a 'cystine mimic' which features an unsaturated bridge; consequently, the dynamics of the spin label are small. This kind of label has been used in 'spinostics' to show that antigens binding 30 to labelled antibody fragments can be detected through changes in the solution-state CW EPR lineshape. ${ }^{195}$ Reaction of a monobromomaleimide (118 or 119, Y $=\mathrm{H}$ ) with a single cysteine results in a maleimide linked label. However, if a pair of cysteines binds through a further conjugate addition reaction, then a succinimide bridge will be formed. ${ }^{196}$ The reactivity of the maleimide labelling agent can be

18 | [journal], [year], [vol], 00-00 
<smiles></smiles>

118: $\mathrm{X}=\mathrm{Br}, \mathrm{OPh}$
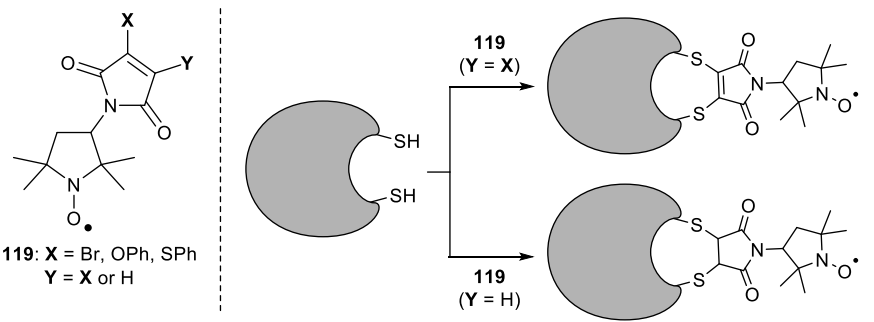

Scheme 15: 'Next-generation' bromomaleimide approach to labelling of cysteines.

tuned by replacing the bromide leaving group(s) with e.g. phenoxy groups, which changes the labelling kinetics or other properties. ${ }^{197}$

5 Other amino acids can also be targeted for labelling. Ideally, these would be labelled through orthogonal linker chemistry, and be naturally sparse. One candidate is the phenol found in tyrosine, where a three-component Mannich-type condensation between a spin label, the tyrosine containing protein (120, Scheme 16) and formaldehyde give either the Mannich product (121) or the benzoxazine rings 10 (122 and 123) through further reaction with formaldehyde. 4-Amino-imidazolinoxyl and aminoisoindoline labels have been employed in this chemistry, and differences in their abilities to measure dynamics characterised. ${ }^{198,199}$

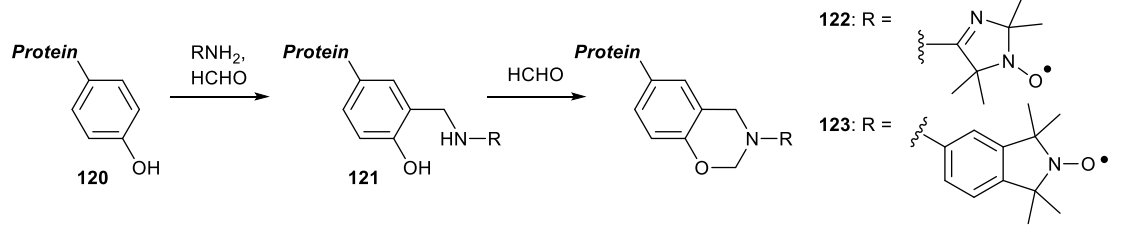

Scheme 16: Spin labelling of proteins at tyrosine residues.

15 Polyhistidine motifs such as $\mathrm{His}_{6}$-tag are commonly introduced at the $\mathrm{N}$ or $\mathrm{C}$ terminus of recombinant proteins for the purpose of purification with nickel affinity columns. PROXYL-tris-nitrilotriacetic acid (P-trisNTA, 124, Figure 14) has a cyclam scaffold with three NTA groups which bind to the polyhistidine-complexed nickel(II) ions, and a linker to a PROXYL nitroxide. ${ }^{200}$ The $\mathrm{T}_{\mathrm{m}}$ of the nickel-bound ${ }_{20} \mathrm{P}$-trisNTA is shorter than that of a standard nitroxide spin label; however, it was successfully used in a DEER experiment to investigate conformational changes in the maltose-binding protein MalE on substrate binding, or the formation of proteinprotein complexes. The DEER-derived distance distributions were fairly broad, but useful information could be extracted. The label also successfully bound to the His${ }_{25}$ tagged MalE in cell lysate, which is promising for future work in live cells.
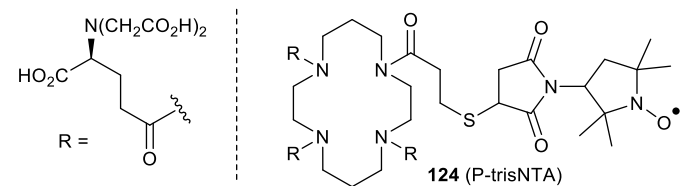

Figure 14: Spin labelling of the $\mathrm{His}_{6}$-tag by binding of P-trisNTA.

Unnatural amino acids may be incorporated into proteins for the purpose of spin labelling. ${ }^{18}$ This strategy can be useful to enable single (orthogonal) labelling of 30 cysteine rich proteins, or to avoid labelling of other natural amino acids. This could

[journal], [year], [vol], 00-00 | 19 
eventually allow labelling of proteins in cells or the incorporation of different types of label. A large number of unnatural amino acids have been incorporated into proteins using expanded genetic code methodologies for a variety of purposes. ${ }^{201}$

For EPR, $p$-acetylphenylalanine has been labelled via an oxime to give the K1 5 side chain (125, Figure 15). Good yields of the unnatural amino acid-containing T4 lysozyme (T4L) protein were obtained in E. coli, however relatively harsh labelling conditions were required ( $\mathrm{pH} 4,37^{\circ} \mathrm{C}$ for 12 hours). The resultant label possessed a large degree of conformational freedom, but has generally proved useful for labelling proteins where cysteines cannot be easily incorporated. ${ }^{202,203}$ The reaction 10 conditions have since been improved through the use of $p$-methoxyaniline as a catalyst, which presumably forms an intermediate (and more electrophilic) ketimine from the acetophenone. ${ }^{204,205} \mathrm{p}$-Azidophenylalanine has also been incorporated into T4L for click cycloadditions: The T1 side chain (126) was created through copperfree, strain promoted, click with a cyclooctyne containing spin label synthesized 15 from the corresponding cyclooctyne carboxylic acid and the amine containing nitroxide. $^{8,206}$ Propargyloxycarbonyl lysine (PocLys) has been incorporated into proteins for click reactions. ${ }^{207-209}$ In work carried out by our groups, two positions of sperm whale myoglobin were mutated to contain PocLys using the expression system of Chin and co-workers. ${ }^{209}$ This was labelled for DEER experiments with 20 azido nitroxide 56 (Scheme 7) via copper-catalysed click conditions (127). However, the results showed some loss of radical and a flexible linker. ${ }^{207,210}$
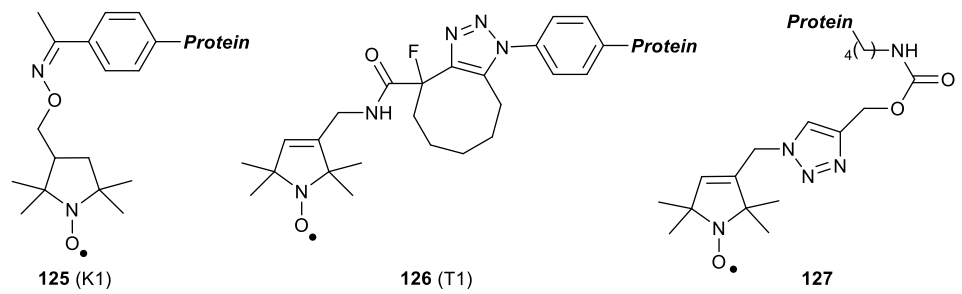

Figure 15: Spin labelling through functionalisation of unnatural amino acids.

There are many advantages to the strategy of incorporating the nitroxide spin ${ }_{25}$ label directly into the protein structure. Amino acid nitroxides such as TOAC (102, Figure 16) and TOPP (128), can be incorporated into small peptides and proteins during solid-phase synthesis. ${ }^{211,212}$ There has also been a report of a pyrrolinoxyl amino acid (129)-containing peptide being chemically ligated through reaction of a $\mathrm{C}$-terminal thioester of the protein and an N-terminal cysteine of the peptide and 30 rearrangement to give a native peptide bond. ${ }^{213,214}$

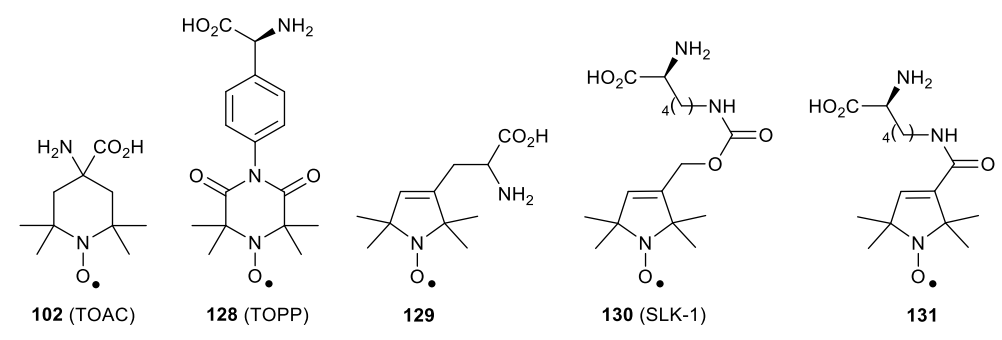

Figure 16: Spin labelling through direct incorporation of nitroxide amino acids.

Arguably the most flexible way of incorporating the nitroxide is through genetic

20 | [journal], [year], [vol], 00-00 
code expansion methodology. Early work necessarily required chemical aminoacylation of the tRNA with the labelled amino acid (cysteine- or tyrosinebased); while successful incorporation was observed, yields were low. ${ }^{215,} 216$ Recently, a highly efficient incorporation of lysine derivative SLK-1 (130) into ${ }_{5}$ thioredoxin has been reported, using E. coli Top10 and RF1 knockout JX33 cells (with higher expression from the latter). ${ }^{54}$ The radical was found to be partially reduced in the cells, although active levels as high as $70 \%$ were possible. As for the propargyl lysine mentioned above, the orthogonal tRNA ${ }^{\mathrm{Pyl}} /$ pyrrolysyl-tRNAsynthetase (PylRS) pair was evolved to accept the SLK-1. The shorter, amide linked, 10 version 131 did not produce a PylRS mutant. ${ }^{54,217}$ Rotamer libraries of the SLK-1 side chain have been produced to aid interpretation of the DEER results. DEER experiments were performed on isolated double SLK-1 mutant thioredoxin. ${ }^{217}$

\subsection{Spin labelling of nucleic acids}

The nucleotides used in DNA and RNA offer a number of potential positions for 15 chemical modification/spin labelling: the pyrimidine and purine rings, the sugar or the phosphodiester (Scheme XX). Labelling is most usefully carried out postoligonucleotide synthesis, which prevents exposure of the nitroxyl to incompatible reaction conditions during solid-phase synthesis (such as TFA or $\mathrm{I}_{2}$ ). Modified DNA synthesis conditions can alternatively be employed to circumvent this issue, and ${ }_{20}$ allow incorporation of spin labels through the solid-phase DNA synthesis. A brief overview of some recent advances in this area will be undertaken here to demonstrate the scope of covalent SDSL in oligonucleotides. ${ }^{218}$

Höbartner, Bennati and co-workers have used 4-amino-TEMPO (39, Scheme 17) with nucleotide precursors carrying leaving groups (132-134) to give $\mathrm{C}, \mathrm{A}$ and $\mathrm{G}$ 25 bases labelled at their exocyclic nitrogen $(\mathbf{1 3 5}-\mathbf{1 3 7}) .{ }^{133,219}$ This was shown to cause little disruption to RNA conformations, and to provide useful distance distributions in DEER experiments. ${ }^{219}$

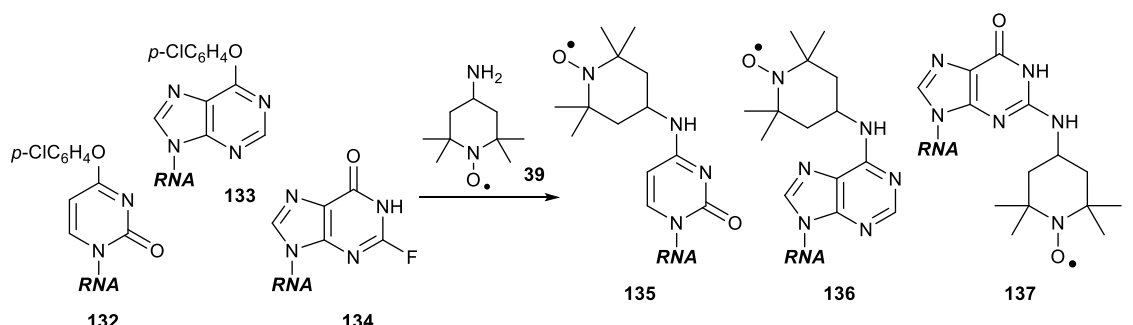

Scheme 17: Nucleophilic installation of a TEMPO spin label on RNA, prior to strand deprotection.

$30 \quad$ The 3,4-dibromomethyl pyrrolinyl nitroxide 108 (Figure 17) has been linked to phosphorothioate groups at adjacent nucleotides in DNA or RNA to give the cyclic $\mathrm{R} 5 \mathrm{c}$ label 138, an analogue of the Rx label used in proteins. ${ }^{220}$ The $2^{\prime}$-position of the ribose may be functionalised in several ways; our groups have recently showed that $\mathrm{U}, \mathrm{C}$ and $\mathrm{A}$ can be alkynylated at this position, which enables a variety of different ${ }_{35}$ azide-containing spin labels to be attached to duplex DNA via CuAAC (139). ${ }^{147}$

It is also possible to synthesise oligonucleotides which contain abasic sites. For example, the polyaromatic spin label ç (140) hydrogen bonds to guanine at an opposing abasic site engineered into a DNA duplex. ${ }^{180,221}$ The labelling efficiency of this compound is high at low temperatures. To enhance binding efficiency, further

[journal], [year], [vol], 00-00|21 
modifications at N3 have been explored. ${ }^{181}$ The ç label was found to bind rigidly enough for distance and orientation data to be determined from DEER signals. In this study DNA duplexes of the LacI operator sequence and one abasic site per strand were doubly labelled with ç and then either measured alone or bound to the ${ }_{5}$ Lac repressor protein which induces duplex bending. ${ }^{222}$
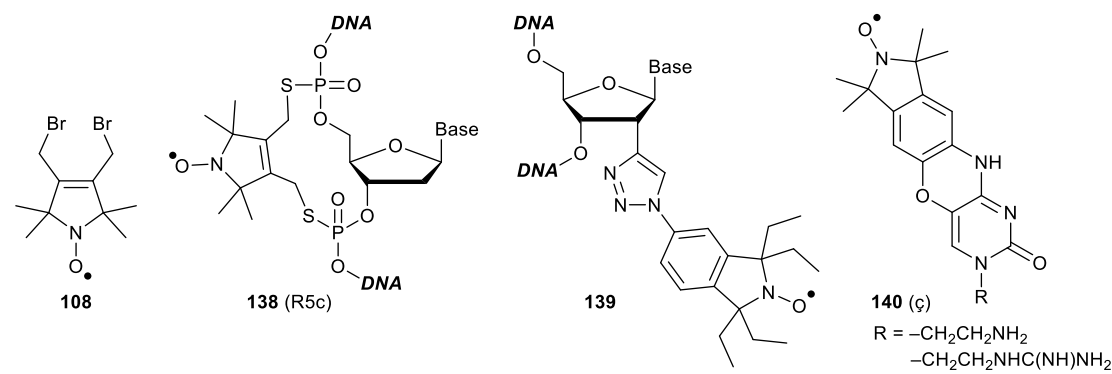

Figure 17: Spin labelling of the phosphodiesters or ribose backbone of DNA, as well as a cytosine analogue for noncovalent SDSL of abasic sites.

Compared to the chemical synthesis of DNA, the reduced coupling efficiency and 10 chemical stability of RNA imparts an upper limit or around 50 ribonucleotides to synthetic RNA, thus rendering most natural (longer) RNAs inaccessible for SDSL. ${ }^{223}$ Two approaches to spin labelling longer RNA targets have been employed: the first uses enzymatic ligation, where short RNA strands containing a 4-thiouridine are spin labelled with iodoacetamido-PROXYL (61, Scheme 7) and ligated together 5 with the unmodified RNA fragments using splinted T4 DNA ligation, without reducing agent DTT, and followed by HPLC purification. ${ }^{224}$ Ligation efficiency was $20-40 \%$ but the final isolated product was estimated to be close to $100 \%$ labelled. The resulting doubly labelled 72-mer nucleotides from the non-coding RNA RsmZ was measured by DEER, together with NMR, experiments to investigate the 20 mechanism for protein sequestration of RsmE in gene expression regulation. ${ }^{225}$

An alternative strategy (Scheme 18) involves binding of [4-( $\mathrm{N}-2$-chloroethyl- $\mathrm{N}$ methylamino)benzyl]-phosphoramide short synthetic DNA sequences to a target sequence of RNA, which then leads to alkylation of the opposing nucleobase. Subsequent hydrolysis of the phosphoramidate bond detaches the short DNA ${ }_{25}$ sequence, and leaves the RNA chemically modified at a specific position. The amino group that has now been introduced is then labelled with an $N$-hydroxysuccinimide ester nitroxide (e.g. 63, Figure 10). ${ }^{226}$ This approach has been used to doubly label the 341 nucleotide IRES site of hepatitis C genomic RNA. Despite a fairly broad distribution of distances in DEER, these results demonstrate exciting new ${ }_{30}$ possibilities for structural studies of long RNAs. ${ }^{27}$

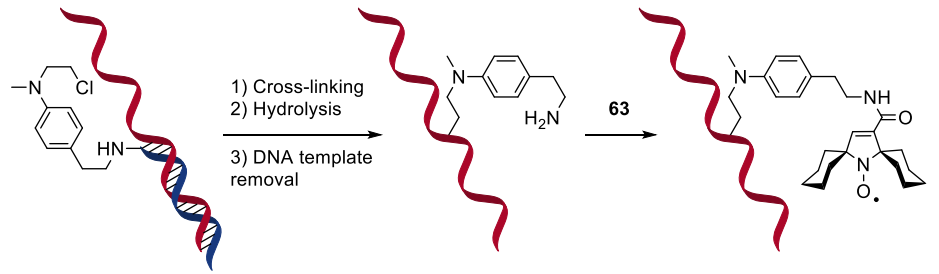

Scheme 18: DNA-templated RNA spin labelling strategy.

22 | [journal], [year], [vol], 00-00

This journal is @ The Royal Society of Chemistry [year] 
Advances have been made to improve the applicability of nitroxide labels for DEER measurements in cells. We have already seen that MTS (18) and TEMPO$\mathrm{CNCbl}(\mathbf{1 1 5}$, Figure 12) allowed for measurements on the outermembrane of E. coli, and that SLK-1 (130, Figure 16) can be biosynthetically incorporated into proteins.

${ }_{5}$ DEER measurements within cells have so far been limited to frog ooycytes, ${ }^{187,217,228}$ in which DEER experiments have been carried out by loading labelled proteins and oligonucleotides by microinjection, and then flash freezing. For example, ubiquitin was double labelled with 3-maleimido-PROXYL (62, Scheme 7), and found to have an approximate radical half-life of 50 minutes. ${ }^{229}$ The distances measured did not 10 vary much from the in vitro results, although with incubation time the SNR for the DEER deteriorated, which manifested as an apparent broadening of the distance distribution. A 7-mer DNA duplex with TEMPA (37, Scheme 5) incorporated at the 5 ' end of each strand demonstrated fast bioreduction and a broader distance distribution when in the cell. ${ }^{230}$ This is possibly due to the DNA denaturing or 15 undergoing processes within the cells. In another study, two RNA structures and a 12-mer DNA duplex labelled with pyrrolinoxyl TPA (57, Scheme 7) have been measured. ${ }^{55}$ Good measurements were possible after 70 minutes incubation time. In this instance the DNA measurements indicated some assembling, possibly end-toend stacking of the duplexes inside the cell, whereas the RNA structures were seen 20 to compare well with in vitro measurements.

\subsection{Spin labelling of other biomolecules}

Other types of biomolecule are also suitable for spin labelling, but have been less widely exploited. For example, in the field of carbohydrates, the highly-sulfated polysaccharide heparin has been partially labelled at the uronic acid or glycosamine ${ }_{25}$ residues using 4-amino-TEMPO (39, Scheme 5), or the activated TEMPO ester 43, to give heparin-polynitroxide derivatives for use in diagnostic and therapeutic applications. ${ }^{231}$ Lipids have also been targeted: the interaction of DOXYL stearic acid (labelled at the 5 and 16 positions from the headgroup, 80, Figure 11) with human and bovine serum albumin has recently been used to probe a variety of 30 structural and dynamics properties. ${ }^{232}$ By utilising the 2-position of the nitroxide as a labelling point it is possible to benefit from a reliable alignment between the magnetic frame of the nitroxide and the labelled substances. ${ }^{39}$ for example, $3 \beta$ DOXYL-5 $\alpha$-cholestane (141, Figure 18) is an analogue of cholesterol and used to probe the structure of membranes. ${ }^{36,39}$ Recent work in this area has investigated the ${ }_{35}$ heterogeneities of membrane structures using electron spin echo decay curves to measure local concentrations. ${ }^{233}$

Imidazolinoxyl (and related imidazolidinoxyl) radicals have been used as $\mathrm{pH}$ sensitive probes in biomolecules, and have been structurally tuned to exhibit a useful range of $\mathrm{p} K_{\mathrm{a}}$ values. $^{16,26,29,30}$ For example, the 1,2-dipalmitoyl-sn-glycero-3${ }_{40}$ phosphothioethanol (PTE) adduct of IKMTS (142) has a $K_{\mathrm{a}}$ of $\sim 6$, whilst that of

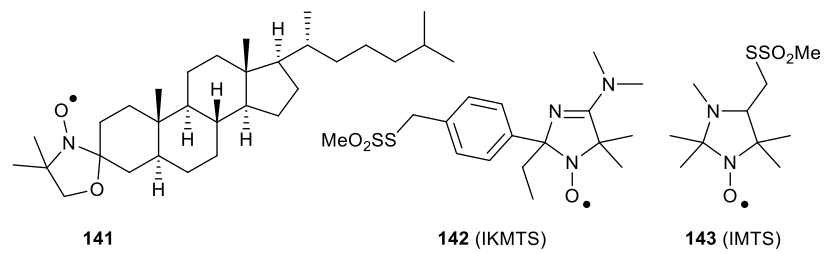

Figure 18: Spin labels used for the investigation of lipids.

[journal], [year], [vol], 00-00 | 23

This journal is (c) The Royal Society of Chemistry [year] 
IMTS (143) has a $\mathrm{p} K_{\mathrm{a}}$ of $\sim 3.3 .{ }^{30}$ Applications of this chemistry have been limited to the labelling of lipids in different environments to explore effects on $\mathrm{p} K_{\mathrm{a}}$ values, ${ }^{30}$ and to the measurement of electrostatic properties in the lipid bilayer. ${ }^{29}$ This so far minor class of spin labels may become significantly more important in the future.

\section{Summary}

Advances in the synthesis of nitroxide spin labels, and associated labelling methods, have broadened the scope of applications of EPR spectroscopy to the study of biomolecules. An intimate knowledge and understanding of the physical aspects that determine relaxation times and radical stability in different environments is

10 fundamental to progressing this wide range of uses. These advances have begun to enable the use of nitroxide spin labels to probe the structure of biomolecules under physiological conditions, a field that looks set to see further developments and discoveries over the coming years.

\section{References}

$1 \quad$ H. El Mkami and D. G. Norman, Methods Enzymol, 2015, 564, 125-152.

2 S. S. Eaton, K. M. More, B. M. Sawant and G. R. Eaton, J. Am. Chem. Soc., 1983, 105, 6560-6567.

3 J. E. Banham, C. M. Baker, S. Ceola, I. J. Day, G. H. Grant, E. J. J. Groenen, C. T.

20 Rodgers, G. Jeschke and C. R. Timmel, Journal of Magnetic Resonance, 2008, 191, $202-$ 218

W. L. Hubbell, D. S. Cafiso and C. Altenbach, Nat Struct Biol, 2000, 7, 735-739.

G. M. Clore and J. Iwahara, Chem. Rev., 2009, 109, 4108-4139.

D. J. Kubicki, G. Casano, M. Schwarzwalder, S. Abel, C. Sauvee, K. Ganesan, M. Yulikov, A. J. Rossini, G. Jeschke, C. Coperet, A. Lesage, P. Tordo, O. Ouari and L. Emsley, Chem. Sci., 2016, 7, 550-558.

7 B. P. Soule, F. Hyodo, K. Matsumoto, N. L. Simone, J. A. Cook, M. C. Krishna and J. B. Mitchell, Free Radical Bio Med, 2007, 42, 1632-1650.

8 W. L. Hubbell, C. J. Lopez, C. Altenbach and Z. Y. Yang, Curr Opin Struc Biol, 2013, $30 \quad$ 23, 725-733.

9 R. Ward and O. Schiemann, Struct Bond, 2014, 152, 249-281.

10 S. A. Shelke and S. T. Sigurdsson, in Struct Bond, eds. C. R. Timmel and J. Harmer, Springer, Berlin, 2014, vol. 152, pp. 121-162

A. J. Fielding, M. G. Concilio, G. Heaven and M. A. Hollas, Molecules, 2014, 19, 1699817025 .

12 K. Hideg, T. Kalai and C. P. Sar, J. Heterocyclic. Chem., 2005, 42, 437-450.

E. G. Rozantsev, Free Nitroxyl Radicals, Springer, New York, 1970.

G. I. Likhtenstein, Spin labeling methods in molecular biology, Wiley, New York, 1976.

R. I. Zhdanov, in Bioactive Spin Labels, ed. R. I. Zhdanov, Springer, Heidelberg, 1992.

E. G. Bagryanskaya, O. A. Krumkacheva, M. V. Fedin and S. R. Marque, Methods Enzymol, 2015, 563, 365-396.

17 K. Hideg and H. O. Hankovszky, in Spin Labeling: theory and applications, eds. L. J. Berliner and J. Reuben, Plenum, 1989, vol. 8.

P. Roser, M. J. Schmidt, M. Drescher and D. Summerer, Org Biomol Chem, 2016.

A. Savitsky, M. Plato and K. Mobius, Appl. Magn. Reson., 2010, 37, 415-434.

H. Hayat and B. L. Silver, J Phys Chem-Us, 1973, 77, 72-78.

O. I. Gromov, E. N. Golubeva, V. N. Khrustalev, T. Kalai, K. Hideg and A. I. Kokorin, Appl. Magn. Reson., 2014, 45, 981-992.

M. Karplus and G. K. Fraenkel, J Chem Phys, 1961, 35, 1312-\&.

R. Owenius, M. Engstrom, M. Lindgren and M. Huber, J Phys Chem A, 2001, 105, 10967-10977.

24 M. Plato, H. J. Steinhoff, C. Wegener, J. T. Torring, A. Savitsky and K. Mobius, Mol Phys, 2002, 100, 3711-3721.

24 | [journal], [year], [vol], 00-00 
E. Bordignon, A. I. Nalepa, A. Savitsky, L. Braun and G. Jeschke, J Phys Chem B, 2015, 119, 13797-13806.

I. A. Kirilyuk, A. A. Bobko, I. A. Grigorev and V. V. Khramtsov, Org. Biomol. Chem., 2004, 2, 1025-1030.

A. I. Smirnov, A. Ruuge, V. A. Reznikov, M. A. Voinov and I. A. Grigor'ev, J. Am. Chem. Soc., 2004, 126, 8872-8873.

V. K. Khlestkin, J. F. Polienko, M. A. Voinov, A. I. Smirnov and V. Chechik, Langmuir, 2008, 24, 609-612.

M. A. Voinov, I. Rivera-Rivera and A. I. Smirnov, Biophysical Journal, 2013, 104, 106116.

M. A. Voinov, I. A. Kirilyuk and A. I. Smirnov, J Phys Chem B, 2009, 113, 3453-3460.

I. A. Kirilyuk, Y. F. Polienko, O. A. Krumkacheva, R. K. Strizhakov, Y. V. Gatilov, I. A. Grigor'ev and E. G. Bagryanskaya, J. Org. Chem., 2012, 77, 8016-8027.

S. R. Burks, M. A. Makowsky, Z. A. Yaffe, C. Hoggle, P. Tsai, S. Muralidharan, M. K. Bowman, J. P. Y. Kao and G. M. Rosen, J. Org. Chem., 2010, 75, 4737-4741.

J. R. Biller, V. Meyer, H. Elajaili, G. M. Rosen, J. P. Y. Kao, S. S. Eaton and G. R. Eaton, J Magn Reson, 2011, 212, 370-377.

A. H. Beth and B. Robinson, H., in Biological Magnetic Resonance, eds. L. J. Berliner and J. Reuben, Plenum, New York, 1989, vol. 8.

B. Gallez, G. Bacic, F. Goda, J. Jiang, J. A. O'Hara, J. F. Dunn and H. M. Swartz, Magn Reson Med, 1996, 35, 97-106.

J. H. Park and W. E. Trommer, in Biological Magnetic Resonance, eds. L. J. Berliner and J. Reuben, Plenum, New York, 1989, vol. 8.

N. L. Breton, M. Martinho, K. Kabytaev, J. Topin, E. Mileo, D. Blocquel, J. Habchi, S. Longhi, A. Rockenbauer, J. Golebiowski, B. Guigliarelli, S. R. A. Marque and V. Belle, Physical Chemistry Chemical Physics, 2014, 16, 4202-4209.

S. Stoll and A. Schweiger, in ESR Spectroscopy in Membrane Biophysics, eds. M. A. Hemminger and L. J. Berliner, Springer, New York, 2007, vol. 27, pp. 299-321.

T. I. Smirnova and A. I. Smirnov, High-field ESR spectroscopy in membrane and protein biophysics, Springer, New York, 2007.

H. J. Steinhoff, R. Mollaaghababa, C. Altenbach, H. G. Khorana and W. L. Hubbell, Biophys Chem, 1995, 56, 89-94.

J. P. Klare and H. J. Steinhoff, Photosynth. Res., 2009, 102, 377-390.

H. S. McHaourab, P. R. Steed and K. Kazmier, Structure, 2011, 19, 1549-1561.

C. J. Lopez, S. Oga and W. L. Hubbell, Biochemistry, 2012, 51, 6568-6583.

M. T. Lerch, J. Horwitz, J. McCoy and W. L. Hubbell, P Natl Acad Sci USA, 2013, 110 , E4714-E4722.

E. Bordignon and Y. Polyhach, Methods Mol Biol, 2013, 974, 329-355.

L. Yu, W. Wang, S. L. Ling, S. L. Liu, L. Xiao, Y. L. Xin, C. H. Lai, Y. Xiong, L. H. Zhang and C. L. Tian, Sci Rep-Uk, 2015, 5.

H. S. McHaourab, M. A. Lietzow, K. Hideg and W. L. Hubbell, Biochemistry, 1996, 35, 7692-7704.

S. Stoll and A. Schweiger, J Magn Reson, 2006, 178, 42-55.

S. Morris, G. Sosnovsky, B. Hui, C. O. Huber, N. U. M. Rao and H. M. Swartz, J Pharm Sci, 1991, 80, 149-152.

T. Yamasaki, F. Mito, Y. Ito, S. Pandian, Y. Kinoshita, K. Nakano, R. Murugesan, K. Sakai, H. Utsumi and K. Yamada, J. Org. Chem., 2011, 76, 435-440.

W. R. Couet, R. C. Brasch, G. Sosnovsky, J. Lukszo, I. Prakash, C. T. Gnewuch and T. N. Tozer, Tetrahedron, 1985, 41, 1165-1172.

A. P. Jagtap, I. Krstic, N. C. Kunjir, R. Hansel, T. F. Prisner and S. T. Sigurdsson, Free Radical Res, 2015, 49, 78-85.

S. Okazaki, M. A. Mannan, K. Sawai, T. Masumizu, Y. Miura and K. Takeshita, Free Radical Research, 2007, 41, 1069-1077.

M. J. Schmidt, J. Borbas, M. Drescher and D. Summerer, J. Am. Chem. Soc., 2014, 136, 1238-1241.

I. Krstic, R. Hansel, O. Romainczyk, J. W. Engels, V. Dotsch and T. F. Prisner, Angew. Chem. Int. Ed., 2011, 50, 5070-5074.

M. Azarkh, O. Okle, P. Eyring, D. R. Dietrich and M. Drescher, J Magn Reson, 2011, 212, 450-454.

I. A. Kirilyuk, A. A. Bobko, S. V. Semenov, D. A. Komarov, I. G. Irtegova, I. A. Grigor'ev and E. Bagryanskaya, J. Org. Chem., 2015, 80, 9118-9125.

[journal], [year], [vol], 00-00|25 


\begin{tabular}{|c|c|}
\hline 58 & 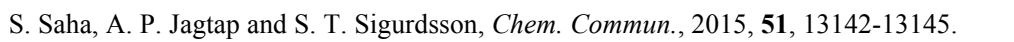 \\
\hline 59 & M. Pink, B. Foley, S. Rajca and A. Rajca, Org Lett, 2012, 14, 5322-5325. \\
\hline 60 & einhart, J. T. Paletta and A. Rajca, Abstr Pap Am Chem S, 2014, 247. \\
\hline 61 & A. Morozov, I. A. Kirilyuk, D. A. Komarov, A. Goti, I. Y. Bagryanskaya, N. V. \\
\hline 5 & Kuratieva and I. A. Grigor'ev, J. Org. Chem., 2012, 77, 10688-10698. \\
\hline 62 & $\begin{array}{l}\text { L. Marx, R. Chiarelli, T. Guiberteau and A. Rassat, J. Chem. Soc., Perkin Trans 1, 2000, } \\
\text { 1181-1182. }\end{array}$ \\
\hline 63 & $\begin{array}{l}\text { G. Jeschke, in Annual Review of Physical Chemistry, Vol 63, eds. M. A. Johnson and T. } \\
\text { J. Martinez, 2012, vol. 63, pp. 419-446. }\end{array}$ \\
\hline 64 & Y. D. Tsvetkov, J Struct Chem+, 2013, 54, S42-S72. \\
\hline 65 & G. Jeschke and Y. Polyhach, Physical Chemistry Chemical Physics, 2007, 9, 1895-1910. \\
\hline 66 & $\begin{array}{l}\text { R. E. Martin, M. Pannier, F. Diederich, V. Gramlich, M. Hubrich and H. W. Spiess, } \\
\text { Angew. Chem. Int. Ed., 1998, 37, 2834-2837. }\end{array}$ \\
\hline 67 & A. D. Milov, K. M. Salikohov and M. D. Shirov, Fizika Tverdogo Tela, 1981, 23, $975-$ \\
\hline 5 & 982. \\
\hline 68 & $\begin{array}{l}\text { P. G. Fajer, L. Brown and L. Song, Practical pulsed dipolar ESR (DEER), Springer, New } \\
\text { York, } 2007 .\end{array}$ \\
\hline 69 & $\begin{array}{l}\text { R. Dastvan, B. E. Bode, M. P. Karuppiah, A. Marko, S. Lyubenova, H. Schwalbe and T. } \\
\text { F. Prisner, J Phys Chem B, 2010, 114, 13507-13516. }\end{array}$ \\
\hline 70 & $\begin{array}{l}\text { G. Jeschke, A. Bender, H. Paulsen, H. Zimmermann and A. Godt, J Magn Reson, 2004, } \\
\text { 169, 1-12. }\end{array}$ \\
\hline 71 & $\begin{array}{l}\text { J. E. Banham, R. J. M. Abbott, S. M. Lea, C. R. Timmel and G. Jeschke, Angew. Chem. } \\
\text { Int. Ed., 2006, 45, 1058-1061. }\end{array}$ \\
\hline 72 & $\begin{array}{l}\text { A. Zecevic, G. R. Eaton, S. S. Eaton and M. Lindgren, Mol Phys, 1998, 95, 1255-1263. } \\
\text { P. P. Borbat, E. R. Georgieva and J. H. Freed, J Phys Chem Lett, 2013, 4, 170-175. }\end{array}$ \\
\hline 74 & $\begin{array}{l}\text { H. El Mkami, R. Ward, A. Bowman, T. Owen-Hughes and D. G. Norman, J Magn } \\
\text { Reson, 2014, 248, 36-41. }\end{array}$ \\
\hline 75 & $\begin{array}{l}\text { R. Ward, A. Bowman, E. Sozudogru, H. El-Mkami, T. Owen-Hughes and D. G. Norman, } \\
\text { J Magn Reson, 2010, 207, 164-167. }\end{array}$ \\
\hline 3076 & $\begin{array}{l}\text { E. J. Hustedt, A. I. Smirnov, C. F. Laub, C. E. Cobb and A. H. Beth, Biophysical } \\
\text { Journal, 1997, 72, Tu388-Tu388. }\end{array}$ \\
\hline 77 & $\begin{array}{l}\text { J. B. Feix, C. A. Popp, S. D. Venkataramu, A. H. Beth, J. H. Park and J. S. Hyde, } \\
\text { Biochemistry, 1984, 23, 2293-2299. }\end{array}$ \\
\hline 78 & G. Jeschke, H. Zimmermann and A. Godt, J Magn Reson, 2006, 180, 137-146. \\
\hline 3579 & $\begin{array}{l}\text { C. Hintze, D. Bucker, S. Domingo Kohler, G. Jeschke and M. Drescher, J Phys Chem } \\
\text { Lett, 2016, 2204-2209. }\end{array}$ \\
\hline 80 & $\begin{array}{l}\text { Z. Yang, Y. Liu, P. Borbat, J. L. Zweier, J. H. Freed and W. L. Hubbell, J. Am. Chem. } \\
\text { Soc., 2012, 134, 9950-9952. }\end{array}$ \\
\hline 81 & V. Meyer, M. A. Swanson, L. J. Clouston, P. J. Boratynski, R. A. Stein, H. S. \\
\hline 40 & $\begin{array}{l}\text { Mchaourab, A. Rajca, S. S. Eaton and G. R. Eaton, Biophysical Journal, 2015, 108, } \\
\text { 1213-1219. }\end{array}$ \\
\hline 82 & $\begin{array}{l}\text { A. A. Kuzhelev, R. K. Strizhakov, O. A. Krumkacheva, Y. F. Polienko, D. A. Morozov, } \\
\text { G. Y. Shevelev, D. V. Pyshnyi, I. A. Kirilyuk, M. V. Fedin and E. G. Bagryanskaya, } \\
\text { Journal of Magnetic Resonance, 2016, 266, 1-7. }\end{array}$ \\
\hline 4583 & $\begin{array}{l}\text { J. E. Lovett, A. M. Bowen, C. R. Timmel, M. W. Jones, J. R. Dilworth, D. Caprotti, S. G. } \\
\text { Bell, L. L. Wong and J. Harmer, Physical Chemistry Chemical Physics, 2009, 11, 6840- } \\
6848 \text {. }\end{array}$ \\
\hline 84 & $\begin{array}{l}\text { M. A. Stevens, J. E. McKay, J. L. Robinson, H. El Mkami, G. M. Smith and D. G. } \\
\text { Norman, Phys Chem Chem Phys, 2016, 18, 5799-5806. }\end{array}$ \\
\hline 5085 & $\begin{array}{l}\text { O. Schiemann, P. Cekan, D. Margraf, T. F. Prisner and S. T. Sigurdsson, Angewandte } \\
\text { Chemie-International Edition, 2009, } 48 \text {. }\end{array}$ \\
\hline 86 & $\begin{array}{l}\text { N. Erlenbach, B. Endeward, P. Schops, D. B. Gophane, S. T. Sigurdsson and T. F. } \\
\text { Prisner, Physical Chemistry Chemical Physics, } 2016 .\end{array}$ \\
\hline 87 & C. Abe, D. Klose, F. Dietrich, W. H. Ziegler, Y. Polyhach, G. Jeschke and H.-J. \\
\hline & \\
\hline 88 & $\begin{array}{l}\text { D. T. Warshaviak, V. V. Khramtsov, D. Cascio, C. Altenbach and W. L. Hubbell, } J \\
\text { Magn Reson, 2013, 232, 53-61. }\end{array}$ \\
\hline 89 & $\begin{array}{l}\text { M. R. Fleissner, M. D. Bridges, E. K. Brooks, D. Cascio, T. Kalai, K. Hideg and W. L. } \\
\text { Hubbell, P Natl Acad Sci USA, 2011, 108, 16241-16246. }\end{array}$ \\
\hline R & D. T. Warshaviak, L. Serbulea, K. N. Houk and W. L. Hubbell, J Phys Chem B, 201 \\
\hline
\end{tabular}

S. Saha, A. P. Jagtap and S. T. Sigurdsson, Chem. Commun., 2015, 51, 13142-13145.

J. T. Paletta, M. Pink, B. Foley, S. Rajca and A. Rajca, Org Lett, 2012, 14, 5322-5325.

E. Reinhart, J. T. Paletta and A. Rajca, Abstr Pap Am Chem S, 2014, 247.

Dorozov, I. A Kirilyuk, D. A. Komarov, A. Goti, I. Y. Bagryanskaya, N. V. L. Marx, R. Chiarelli, T. Guiberteau and A. Rassat, J. Chem. Soc., Perkin Trans 1, 2000, 1181-1182.

J. Martinez, 2012, vol. 63, pp. 419-446.

Y. D. Tsvetkov, J Struct Chem+, 2013, 54, S42-S72. Angew. Chem. Int. Ed., 1998, 37, 2834-2837. 982 York, 2007.

F. Prisner, J Phys Chem B, 2010, 114, 13507-13516.

Jeschke, A. Bender, H. Paulsen, H. Zimmernan

Abbott, S. M. Lea, C. R. Timmel and G. Jeschke, Angew. Chem. Int. Ed., 2006, 45, 1058-1061.

Borbat, E. R. Georgieva and J. H. Fred,

Reson, 2014, 248, 36-41

J Magn Reson, 2010, 207, 164-167.

Journal, 1997, 72, Tu388-Tu388.

. Feix, C. A. Popp, S. D. Venkataramu, A. H. Beth, J.H. Park and J. S. Hyde,

C. Hintze, D. Bucker, S. Domingo Kohler, G. Jeschke and M. Drescher, J Phys Chem Z. Yang, Y. Liu, P. Borbat, J. L. Zweier, J. H. Freed and W. L. Hubbell, J. Am. Chem. Soc., 2012, 134, 9950-9952. 1213-1219. Journal of Magnetic Resonance, 2016, 266, 1-7.

Bell, L. L. Wong and J. Harmer, Physical Chemistry Chemical Physics, 2009, 11, 6840-

O. Schiemann, P. Cekan, D. Margraf, T. F. Prisner and S. T. Sigurdsson, Angewandte Chemie-International Edition, 2009, 48

Steinhoff, J Magn Reson, 2012, 216, 53-61. Magn Reson, 2013, 232, 53-61.

Hubbell, P Natl Acad Sci USA, 2011, 108, 16241-16246.

115, 397-405.

26 | [journal], [year], [vol], 00-00 


\begin{tabular}{|c|c|}
\hline 91 & $\begin{array}{l}\text { Z. W. Zhang, M. R. Fleissner, D. S. Tipikin, Z. C. Liang, J. K. Moscicki, K. A. Earle, W. } \\
\text { L. Hubbell and J. H. Freed, J Phys Chem B, 2010, 114, 5503-5521. }\end{array}$ \\
\hline 92 & ridges, K. Hideg and W. L. Hubbell, Appl. Magn. Reson., 2010, 37, 363-390. \\
\hline 93 & Sezer, J. H. Freed and B. Roux, J. Am. Chem. Soc., 2009, 131, 2597-2605. \\
\hline 94 & $\begin{array}{l}\text { D. E. Budil, K. L. Sale, K. A. Khairy and P. G. Fajer, J Phys Chem A, 2006, 110, 3703- } \\
\text { 3713. }\end{array}$ \\
\hline 95 & C. Beier and H. J. Steinhoff, Biophysical Journal, 2006, 91, 2647-2664. \\
\hline 96 & $\begin{array}{l}\text { S. C. DeSensi, D. P. Rangel, A. H. Beth, T. P. Lybrand and E. J. Hustedt, Biophysical } \\
\text { Journal, 2008, 94, 3798-3809. }\end{array}$ \\
\hline & $\begin{array}{l}\text { M. m. M. Hatmal, Y. Li, B. G. Hegde, P. B. Hegde, C. C. Jao, R. Langen and I. S. } \\
\text { Haworth, Biopolymers, 2012, 97, 35-44. }\end{array}$ \\
\hline 98 & D. Sezer, J. H. Freed and B. Roux, J Phys Chem B, 2008, 112, 5755-5767. \\
\hline 99 & Sezer and S. T. Sigurdsson, Phys Chem Chem Phys, 2 \\
\hline 100 & $\begin{array}{l}\text { J. E. D. Lillington, J. E. Lovett, S. Johnson, P. Roversi, C. R. Timmel and S. M. Lea, } J \\
\text { Mol Biol, } 2011, \mathbf{4 0 5}, 427-435 .\end{array}$ \\
\hline 101 & J. C. Hsia and L. H. Piette, Arch Biochem Biophys, 1969, 129, 296-\&. \\
\hline 102 & G. Jeschke, Prog Nucl Ma \\
\hline 103 & $\begin{array}{l}\text { Y. Polyhach, E. Bordignon and G. Jeschke, Physical Chemistry Chemical Physics, 2011, } \\
\text { 13, 2356-2366. }\end{array}$ \\
\hline 04 & $\begin{array}{l}\text { W. R. Dolbier, H. Koroniak, K. N. Houk and C. M. Sheu, Acc. Chem. Res., 1996, 29, } \\
\text { 471-477. }\end{array}$ \\
\hline 105 & $\begin{array}{l}\text { K. N. Beasley, B. T. Sutch, M. M. Hatmal, R. Langen, P. Z. Qin and I. S. Haworth, } \\
\text { Methods Enzymol, 2015, 563, 569-593. }\end{array}$ \\
\hline 106 & https://ihlab.hsc. \\
\hline 07 & $\begin{array}{l}\text { G. Hagelueken, R. Ward, J. H. Naismith and O. Schiemann, Appl. Magn. Reson., 2012, } \\
\text { 42, 377-391. }\end{array}$ \\
\hline 108 & http://pymolwiki.org/index.php/MtsslWizard. \\
\hline 109 & $\begin{array}{l}\text { inco, A. S. Micallef, S. E. Bottle, S. S. Eaton } \\
-2151 .\end{array}$ \\
\hline 10 & $\begin{array}{l}\text { V. Kathirvelu, C. Smith, C. Parks, M. A. Mannan, Y. Miura, K. Takeshita, S. S. Eaton } \\
\text { and G. R. Eaton, Chemical Communications, 2009, 454-456. }\end{array}$ \\
\hline 111 & $\begin{array}{l}\text { A. Rajca, V. Kathirvelu, S. K. Roy, M. Pink, S. Rajca, S. Sarkar, S. S. Eaton and G. R. } \\
\text { Eaton, Chemistry-a European Journal, 2010, 16, 5778-5782. }\end{array}$ \\
\hline 112 & $\begin{array}{l}\text { A. A. Kuzhelev, R. K. Strizhakov, O. A. Krumkacheva, Y. F. Polienko, D. A. Morozov, } \\
\text { G. Y. Shevelev, D. V. Pyshnyi, I. A. Kirilyuk, M. V. Fedin and E. G. Bagryanskaya, J } \\
\text { Magn Reson, 2016, 266, 1-7. }\end{array}$ \\
\hline 113 & Y. Miura, N. Nakamura and I. Taniguchi, Macromolecules, 2001, 34, 447-455. \\
\hline 114 & $\begin{array}{l}\text { V. D. Sen, V. A. Golubev and N. N. Efremova, Bulletin of the Academy of Sciences of } \\
\text { the USSR, Division of chemical science, } 1982, \mathbf{3 1}, 53-63 \text {. }\end{array}$ \\
\hline 110 & $\begin{array}{l}\text { K. Yamada, Y. Kinoshita, T. Yamasaki, H. Sadasue, F. Mito, M. Nagai, S. Matsumoto, } \\
\text { M. Aso, H. Suemune, K. Sakai and H. Utsumi, Arch. Pharm. Chem. Life Sci., 2008, 341, } \\
548-553 \text {. }\end{array}$ \\
\hline 116 & J. A. Cella, J. A. Kelley and E. F. Keneh \\
\hline 117 & \\
\hline 118 & hem. Soc \\
\hline 119 & $\begin{array}{l}\text { Y. Wang, J. T. Paletta, K. Berg, E. Reinhart, S. Rajca and A. Rajca, Org. Lett., 2014, 16, } \\
5298-5300 .\end{array}$ \\
\hline 120 & $\begin{array}{l}\text { J. A. Cella, J. A. Kelley and E. F. Kenehan, J. Chem. Soc., Chem. Commun., 1974, } 943- \\
943 .\end{array}$ \\
\hline 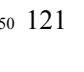 & $\begin{array}{l}\text { B. A. Chalmers, J. C. Morris, K. E. Fairfull-Smith, R. S. Grainger and S. E. Bottle, } \\
\text { Chem. Commun., 2013, 49, 10382-10384. }\end{array}$ \\
\hline 122 & $\begin{array}{l}\text { I. Seven, T. Weinrich, M. Granz, C. Grunewald, S. Bruss, I. Krstic, T. F. Prisner, A. } \\
\text { Heckel and M. W. Gobel, Eur. J. Org. Chem., 2014, 4037-4043. }\end{array}$ \\
\hline 123 & $\begin{array}{l}\text { K. Sakai, K. Yamada, T. Yamasaki, Y. Kinoshita, F. Mito and H. Utsumi, Tetrahedron, } \\
\text { 2010, 66, 2311-2315. }\end{array}$ \\
\hline 124 & $\begin{array}{l}\text { C. Wetter, J. Gierlich, C. A. Knoop, C. Muller, T. Schulte and A. Studer, Chem. Eur. J., } \\
2004,10,1156-1166 .\end{array}$ \\
\hline 12. & T. Yoshioka, Higashid.S and K. Murayama, Bull. Chem. Soc. Jpn., 1972, 45, 63 \\
\hline & $\begin{array}{l}\text { J. Krim, M. Taourirte, C. Grünewald, I. Krstic and J. W. Engels, Synthesis, 2013, } 4 \\
396-405\end{array}$ \\
\hline
\end{tabular}

[journal], [year], [vol], 00-00 | 27 


\begin{tabular}{|c|c|}
\hline 27 & $\begin{array}{l}\text { A. Shelke, G. B. Sandholt and S. T. Sigurdsson, Org. Biomol. Chem., 2014, 12, 7366- } \\
\text { 7374. }\end{array}$ \\
\hline 128 & $\begin{array}{l}\text { M. Azarkh, V. Singh, O. Okle, I. T. Seemann, D. R. Dietrich, J. S. Hartig and M. } \\
\text { Drescher, Nat. Protocols, 2013, 8, 131-147. }\end{array}$ \\
\hline 129 & $\begin{array}{l}\text { V. Singh, M. Azarkh, M. Drescher and J. S. Hartig, Chem. Commun., 2012, 48, 8258- } \\
8260 .\end{array}$ \\
\hline 130 & $\begin{array}{l}\text { V. Singh, M. Azarkh, T. E. Exner, J. S. Hartig and M. Drescher, Angew. Chem. Int. Ed., } \\
\text { 2009, 48, 9728-9730. }\end{array}$ \\
\hline 131 & $\begin{array}{l}\text { P. Ding, D. Wunnicke, H.-J. Steinhoff and F. Seela, Chem. Eur. J., 2010, 16, 14385- } \\
14396 .\end{array}$ \\
\hline 132 & $\begin{array}{l}\text { A. L. Kleschyov, V. Sen, V. Golubev, K. Münnemann, D. Hinderberger, K. J. Lackner, } \\
\text { S. Weber, M. Terekhov, L. M. Schreiber and T. Münzel, European Journal of Medicinal } \\
\text { Chemistry, 2012, 58, 265-271. }\end{array}$ \\
\hline 133 & $\begin{array}{l}\text { K. Halbmair, J. Seikowski, I. Tkach, C. Hobartner, D. Sezer and M. Bennati, Chem. Sci., } \\
2016,7,3172-3180 .\end{array}$ \\
\hline 134 & D. B. Gophane and S. T. Sigurdsson, Beilstein J. Org. Chem., 2015, 11, 219-227. \\
\hline 135 & $\begin{array}{l}\text { G. Sicoli, F. Wachowius, M. Bennati and C. Höbartner, Angew. Chem. Int. Ed., 2010, } \mathbf{4 9} \text {, } \\
6443-6447 \text {. }\end{array}$ \\
\hline 136 & and S. T. Sigurdsson, J. Am. Chem. Soc., 2009, 131, 18054-18056. \\
\hline 12 & $\begin{array}{l}\text { G. Sicoli, G. Mathis, O. Delalande, Y. Boulard, D. Gasparutto and S. Gambarelli, Angew. } \\
\text { Chem. Int. Ed., 2008, 47, 735-737. }\end{array}$ \\
\hline 138 & $\begin{array}{l}\text { J. P. Gölz, S. Bockelmann, K. Mayer, H.-J. Steinhoff, H. Wieczorek, M. Huss, J. P. Klare } \\
\text { and D. Menche, Chemmedchem, 2016, 11, 420-428. }\end{array}$ \\
\hline 139 & $\begin{array}{l}\text { T. E. Edwards, T. M. Okonogi, B. H. Robinson and S. T. Sigurdsson, J. Am. Chem. Soc., } \\
\text { 2001, 123, 1527-1528. }\end{array}$ \\
\hline 140 & $\begin{array}{l}\text { J. Zakrzewski, J. Hupko and K. Kryczka, Monatshefte für Chemie / Chemical Monthly, } \\
\text { 2003, 134, 843-850. }\end{array}$ \\
\hline 141 & $\begin{array}{l}\text { A. Cecchi, L. Ciani, J.-Y. Winum, J.-L. Montero, A. Scozzafava, S. Ristori and C. T. } \\
\text { Supuran, Bioorg. Med. Chem. Lett., 2008, 18, 3475-3480. }\end{array}$ \\
\hline 14 & I. Org. Chem., 1976, 41, 564-565. \\
\hline & \\
\hline 144 & $\begin{array}{l}\text { E. A. W. van der Cruijsen, E. J. Koers, C. Sauvée, R. E. Hulse, M. Weingarth, O. Ouari, } \\
\text { E. Perozo, P. Tordo and M. Baldus, Chem. Eur. J., 2015, 21, 12971-12977. }\end{array}$ \\
\hline 145 & $\begin{array}{l}\text { C. Sauvée, M. Rosay, G. Casano, F. Aussenac, R. T. Weber, O. Ouari and P. Tordo, } \\
\text { Angew. Chem. Int. Ed., 2013, 52, 10858-10861. }\end{array}$ \\
\hline 146 & $\begin{array}{l}\text { V. Meyer, M. A. Swanson, L. J. Clouston, P. J. Boratynski, R. A. Stein, H. S. } \\
\text { McHaourab, A. Rajca, S. S. Eaton and G. R. Eaton, Biophys J, 2015, 108, 1213-1219. }\end{array}$ \\
\hline 147 & $\begin{array}{l}\text { M. M. Haugland, A. H. El-Sagheer, R. J. Porter, J. Peña, T. Brown, E. A. Anderson and } \\
\text { J. E. Lovett, 2016, Submitted. }\end{array}$ \\
\hline & Makinen, \\
\hline & $\begin{array}{l}\text { B. Hatano, H. Araya, Y. Yoshimura, H. Sato, T. Ito, T. Ogata and T. Kijima, } \\
\text { Heterocycles, 2010, 81, 349-356. }\end{array}$ \\
\hline 150 & $\begin{array}{l}\text { I. A. Kirilyuk, Y. F. Polienko, O. A. Krumkacheva, R. K. Strizhakov, Y. V. Gatilov, I. A. } \\
\text { Grigor'ev and E. G. Bagryanskaya, Journal of Organic Chemistry, 2012, 77, 8016-8027. }\end{array}$ \\
\hline 1 & $5,1244-1250$. \\
\hline & \\
\hline 153 & $\begin{array}{l}\text { L. J. Berliner, J. Grunwald, H. O. Hankovszky and K. Hideg, Anal Biochem, 1982, 119, } \\
\text { 450-455. }\end{array}$ \\
\hline 154 & H. O. Hankovszky, K. Hideg and L. Lex, Synthesis, 1981, 1 \\
\hline 10 & 4. \\
\hline 156 & , G. Gulyas-Fekete and K. Hideg, Synth. Commun., \\
\hline 15 & T. Kálai, M. Balog, J. Jekö and K \\
\hline & kenbauer and J. L. Zweier, J. Org \\
\hline & \\
\hline 159 & S. Ogawa and H. M. McConnell, Proc. Nat. Acad. Sci., 1967, 58, 19-26. \\
\hline 10 & \\
\hline 161 & $\begin{array}{l}\text { A. Rajca, Y. Wang, M. Boska, J. T. Paletta, A. Olankitwanit, M. A. Swanson, D. G. } \\
\text { Mitchell, S. S. Eaton, G. R. Eaton and S. Rajca, J. Am. Chem. Soc., 2012, 134, 15724- } \\
15727 .\end{array}$ \\
\hline
\end{tabular}

28 | [journal], [year], [vol], 00-00 
Y. F. Polienko, O. A. Snytnikova, V. V. Yanshole, E. I. Chernyak, S. V. Morozov, I. A. Grigor'ev and Y. P. Tsentalovich, J. Photochem. Photobiol. A: Chemistry, 2016, 322323, 76-84.

A. Y. Misharin and N. G. Bushmakina, Synthesis, 1985, 1985, 656-659. 625 .

10167 K. E. Fairfull-Smith, F. Brackmann and S. E. Bottle, Eur. J. Org. Chem., 2009, 19021915.

A. S. Micallef, R. C. Bott, S. E. Bottle, G. Smith, J. M. White, K. Matsuda and H. Iwamura, J Chem Soc Perk T 2, 1999, 65-71. Sutcliffe, J Chem Soc Perk T 2, 2000, 1285-1291.

T. R. Miller and P. B. Hopkins, Bioorg. Med. Chem. Lett., 1994, 4, 981-986.

S. Saha, A. P. Jagtap and S. T. Sigurdsson, Chem. Commun., 2015, 51, 13142-13145.

U. Jakobsen, S. A. Shelke, S. Vogel and S. T. Sigurdsson, J. Am. Chem. Soc., 2010, 132, 10424-10428.

K. E. Fairfull-Smith, E. A. Debele, J. P. Allen, M. C. Pfrunder and J. C. McMurtrie, Eur. J. Org. Chem., 2013, 4829-4835.

J. P. Blinco, J. L. Hodgson, B. J. Morrow, J. R. Walker, G. D. Will, M. L. Coote and S. E. Bottle, J. Org. Chem., 2008, 73, 6763-6771.

D. J. Keddie, K. E. Fairfull-Smith and S. E. Bottle, Org. Biomol. Chem., 2008, 6, 31353143.

N. Barhate, P. Cekan, A. P. Massey and S. T. Sigurdsson, Angewandte ChemieInternational Edition, 2007, 46, 2655-2658.

D. B. Gophane and S. T. Sigurdsson, Chem. Commun., 2013, 49, 999-1001.

D. B. Gophane, B. Endeward, T. F. Prisner and S. T. Sigurdsson, Chem. Eur. J., 2014, 20, 15913-15919.

M. Sajid, G. Jeschke, M. Wiebcke and A. Godt, Chem. Eur. J., 2009, 15, 12960-12962.

S. A. Shelke and S. T. Sigurdsson, Angew. Chem. Int. Ed., 2010, 49, 7984-7986.

S. A. Shelke and S. T. Sigurdsson, ChemBioChem, 2012, 13, 684-690.

C. Toniolo, M. Crisma and F. Formaggio, Biopolymers, 1998, 47, 153-158.

T. Kalai, J. Jeko and K. Hideg, Synthesis, 2009, 2591-2595.

G. Ur, T. Kalai and K. Hideg, Tetrahedron Lett., 2016, 57, 778-780.

A. P. Todd, V. Crozel, F. Levinthal, C. Levinthal and W. Hubbell, Biophysical Journal, 1987, 51, A83-A83.

B. Joseph, A. Sikora, E. Bordignon, G. Jeschke, D. S. Cafiso and T. F. Prisner, Angew. Chem. Int. Ed., 2015, 54, 6196-6199.

B. Joseph, A. Sikora and D. S. Cafiso, J. Am. Chem. Soc., 2016, 138, 1844-1847.

L. Columbus, T. Kalai, J. Jeko, K. Hideg and W. L. Hubbell, Biochemistry, 2001, 40, 3828-3846.

J. F. W. Keana, K. Hideg, G. B. Birrell, O. H. Hankovszky, G. Ferguson and M. Parvez, Can. J. Chem, 1982, 60, 1439-1447.

T. Kalai, M. Balog, J. Jeko and K. Hideg, Synthesis, 1999, 973-980.

N. L. Fawzi, M. R. Fleissner, N. J. Anthis, T. Kalai, K. Hideg, W. L. Hubbell and G. M. Clore, J Biomol Nmr, 2011, 51, 105-114.

V. V. Khramtsov, V. I. Yelinova, L. M. Weiner, T. A. Berezina, V. V. Martin and L. B. Volodarsky, Analytical Biochemistry, 1989, 182, 58-63.

I. D. Sahu, R. M. McCarrick, K. R. Troxel, R. F. Zhang, H. J. Smith, M. M. Dunagan, M. S. Swartz, P. V. Rajan, B. M. Kroncke, C. R. Sanders and G. A. Lorigan, Biochemistry, 2013, 52, 6627-6632.

. E. B. Smith, F. F. Schumacher, C. P. Ryan, L. M. Tedaldi, D. Papaioannou, G. Waksman, S. Caddick and J. R. Baker, J. Am. Chem. Soc., 2010, 132, 1960-1965.

F. F. Schumacher, V. A. Sanchania, B. Tolner, Z. V. F. Wright, C. P. Ryan, M. E. B. Smith, J. M. Ward, S. Caddick, C. W. M. Kay, G. Aeppli, K. A. Chester and J. R. Baker, Sci Rep-Uk, 2013, 3. 


\begin{tabular}{|c|c|}
\hline 197 & Marculescu, H. Kossen, R. E. Morgan, P. \\
\hline 198 & Lorenzi, C. Puppo, R. \\
\hline & \\
\hline & $11, \mathbf{5 0}, 9108-9111$. \\
\hline 199 & $\begin{array}{l}\text { E. Mileo, E. Etienne, M. Martinho, R. Lebrun, V. Roubaud, P. Tordo, B. Gontero, B. } \\
\text { Guigliarelli, S. R. A. Marque and V. Belle, Bioconjugate Chem, 2013, 24, 1110-1117. }\end{array}$ \\
\hline 200 & $\begin{array}{l}\text { C. Baldauf, K. Schulze, P. Lueders, E. Bordignon and R. Tampe, Chem. Eur. J., 2013, } \\
\text { 19, 13714-13719. }\end{array}$ \\
\hline 01 & K. Lang and J. W. Chin, Chem. Rev., 2014, 114, 4764-4806. \\
\hline 202 & $\begin{array}{l}\text { M. R. Fleissner, E. M. Brustad, T. Kalai, C. Altenbach, D. Cascio, F. B. Peters, K. Hideg, } \\
\text { S. Peuker, P. G. Schultz and W. L. Hubbell, P Natl Acad Sci USA, 2009, 106, 21637- } \\
21642 .\end{array}$ \\
\hline 203 & A. R. Spevacek, E. G. B. Evans, J. L. Miller, H. C. Meyer, J. G. Pelton and G. L. \\
\hline & illhauser, Structure, 2013, 21, 236-246. \\
\hline 204 & $\begin{array}{l}\text { A. Hahn, S. Reschke, S. Leimkuhler and T. Risse, J Phys Chem B, 2014, 118, 7077- } \\
7084 .\end{array}$ \\
\hline 205 & G. B. Evans and G. L. Millhauser, Method Enzymol, 2015, 563, 503-527. \\
\hline 06 & $\begin{array}{l}\text { T. Kalai, M. R. Fleissner, J. Jeko, W. L. Hubbell and K. Hideg, Tetrahedron Lett., 2011, } \\
\mathbf{5 2 , 2 7 4 7 - 2 7 4 9 .}\end{array}$ \\
\hline 207 & drews, 2016. \\
\hline & $\begin{array}{l}\text { Suvorina, D. Klose, S. Korneev, D. Grohmann, E. A. Lemke, J. P. Klare and H. J. } \\
\text { einhoff, 49th Annual Internation Metting of the ESR Spectroscopy Group of the Royal } \\
\text { cciey of Chemistry, Colchester, UK, } 2016 \text {. }\end{array}$ \\
\hline & $\begin{array}{l}\text { D. P. Nguyen, H. Lusic, H. Neumann, P. B. Kapadnis, A. Deiters and J. W. Chin, J. Am. } \\
\text { Chem. Soc., 2009, 131, } 8720-+ \text {. }\end{array}$ \\
\hline 210 & $\begin{array}{l}\text { B. Hajjaj, S. Bell and J. E. Lovett, 57th Rocky Mountain Conference on Magnetic } \\
\text { Resonance, Snowbird, Utah, USA, } 2015 .\end{array}$ \\
\hline 11 & $\begin{array}{l}\text { S. Schreier, J. C. Bozelli, Jr., N. Marin, R. F. Vieira and C. R. Nakaie, Biophys Rev, } \\
2012,4,45-66 \text {. }\end{array}$ \\
\hline 212 & $\begin{array}{l}\text { S. Stoller, G. Sicoli, T. Y. Baranova, M. Bennati and U. Diederichsen, Angew. Chem. Int. } \\
\text { Ed., 2011, 50, 9743-9746. }\end{array}$ \\
\hline 213 & $\begin{array}{l}\text { M. R. Balog, T. K. Kalai, J. Jeko, H. J. Steinhoff, M. Engelhard and K. Hideg, Synlett, } \\
\text { 2004, 2591-2593. }\end{array}$ \\
\hline & $\begin{array}{l}\text { C. F. W. Becker, K. Lausecker, M. Balog, T. Kalai, K. Hideg, H. J. Steinhoff and M. } \\
\text { Engelhard, Magnetic Resonance in Chemistry, 2005, 43, S34-S39. }\end{array}$ \\
\hline 215 & $\begin{array}{l}\text { A. M. Shafer, T. Kalai, S. Q. B. Liu, K. Hideg and J. C. Voss, Biochemistry, 2004, 43, } \\
8470-8482 .\end{array}$ \\
\hline & $\begin{array}{l}\text { V. W. Cornish, D. R. Benson, C. A. Altenbach, K. Hideg, W. L. Hubbell and P. G. } \\
\text { Schultz, P Natl Acad Sci USA, 1994, 91, 2910-2914. }\end{array}$ \\
\hline 217 & $\begin{array}{l}\text { J. Schmidt, A. Fedoseev, D. Bucker, J. Borbas, C. Peter, M. Drescher and D. } \\
\text { mmerer, Acs Chem Biol, 2015, 10, 2764-2771. }\end{array}$ \\
\hline 18 & $\begin{array}{l}\text { S. A. Shelke and S. T. Sigurdsson, in Modified Nucleic Acids, eds. K. Nakatani and Y. } \\
\text { Tor, Springer, Switzerland, 2016, vol. 31, pp. 159-187. }\end{array}$ \\
\hline & $\begin{array}{l}\text { G. Sicoli, F. Wachowius, M. Bennati and C. Hobartner, Angew. Chem. Int. Ed., 2010, 49, } \\
\text { 6443-6447. }\end{array}$ \\
\hline 22 & P. H. Nguyen, A. M. Popova, K. Hideg and P. Z. \\
\hline & \\
\hline & $\begin{array}{l}\text { G. W. Reginsson, S. A. Shelke, C. Rouillon, M. F. White, S. T. Sigurdsson and O. } \\
\text { Schiemann, Nucleic Acids Res, 2013, 41, e11. }\end{array}$ \\
\hline 223 & roc. Nat. Acad. Sci., 2010, 107, 15329-15334. \\
\hline & 2014, 5. \\
\hline 225 & $\begin{array}{l}\text { O. Duss, E. Michel, M. Yulikov, M. Schubert, G. Jeschke and F. H. T. Allain, Nature, } \\
\text { 2014, 509, 588-+. }\end{array}$ \\
\hline & $\begin{array}{l}\text { E. S. Babaylova, A. V. Ivanov, A. A. Malygin, M. A. Vorobjeva, A. G. Venyaminova, Y. } \\
\text { F. Polienko, I. A. Kirilyuk, O. A. Krumkacheva, M. V. Fedin, G. G. Karpova and E. G. } \\
\text { Bagryanskaya, Org Biomol Chem, 2014, 12, 3129-3136. }\end{array}$ \\
\hline & $\begin{array}{l}\text { E. S. Babaylova, A. A. Malygin, A. A. Lomzov, D. V. Pyshnyi, M. Yulikov, G. Jeschke, } \\
\text { O. A. Krumkacheva, M. V. Fedin, G. G. Karpova and E. G. Bagryanskaya, Nucleic Acids } \\
\text { Res, } 2016 \text {. }\end{array}$ \\
\hline
\end{tabular}

30 | [journal], [year], [vol], 00-00 
S. Dunkel, L. P. Pulagam, H. J. Steinhoff and J. P. Klare, Physical Chemistry Chemical Physics, 2015, 17, 4875-4878.

229 R. Igarashi, T. Sakai, H. Hara, T. Tenno, T. Tanaka, H. Tochio and M. Shirakawa, J. Am. Chem. Soc., 2010, 132, 8228-+.

5230 M. Azarkh, O. Okle, V. Singh, I. T. Seemann, J. S. Hartig, D. R. Dietrich and M. Drescher, ChemBioChem, 2011, 12, 1992-1995.

231 A. L. Kleschyov, V. Sen', V. Golubev, K. Munnemann, D. Hinderberger, K. J. Lackner, S. Weber, M. Terekhov, L. M. Schreiber and T. Munzel, European Journal of Medicinal Chemistry, 2012, 58, 265-271.

232 J. Reichenwallner and D. Hinderberger, Bba-Gen Subjects, 2013, 1830, 5382-5393.

233 M. E. Kardash, N. P. Isaev and S. A. Dzuba, J Phys Chem B, 2015, 119, 13675-13679.

[journal], [year], [vol], 00-00 | 31 